\title{
Glass production in Late Antiquity and the Early Islamic period: a geochemical perspective
}

\author{
Ian C. Freestone
}

\begin{abstract}
First millennium A.D. glass production was divided between a relatively small number of workshops that made raw glass and a large number of secondary workshops that fabricated vessels. Glass compositions reflect the primary glassmaking source. For most of the period, Egyptian mineral soda was fused with lime-bearing siliceous sand to produce soda-lime-silica glass. The location of the Belus glassmaking sand, which is known from the classical literature, is located on that part of the Levantine coast where iron contents are lowest. ${ }^{87} \mathrm{Sr} /{ }^{86} \mathrm{Sr}$ of primary glass from workshops in the Levantine region is close to modern sea water, and confirms the use of beach sand, which contained shell. Heavy mineral assemblages of Levantine beach sands are dominated by hornblende, hence the primary glasses are characterised by very similar trace element signatures. Glasses believed on archaeological grounds to have been made in other regions, for example in inland Egypt, may have higher ${ }^{87} \mathrm{Sr} /{ }^{86} \mathrm{Sr}$, reflecting terrigenous sources of lime, and have different trace element signatures. Compositional data for glasses from as far away as Britain suggest origins of the glass material in the Eastern Mediterranean. Recycling of old glass may be recognised by the presence of elevated transition metals. The use of plant ash as a flux became dominant practice in the ninth century and preliminary data for plant ash glasses from the early Islamic world indicate that primary production centres may be separated using strontium and oxygen isotopes as well as by major and trace elements.
\end{abstract}


Small glass objects, such as beads and pendants, are reported from the archaeological record as far back as the late third millennium B.C., but production of glass vessels on any significant scale seems to have begun in the Late Bronze Age, in the late sixteenth century to mid-fifteenth B.C., in northern Syria and Mesopotamia (Moorey 1994) and at about the same time in Egypt (Lilyquist \& Brill 1993). Glass at this time was strongly coloured and a rare material of high status, equated with semi-precious stones such as lapis lazuli (Oppenheim et al. 1970).

Glass is relatively rare in the so-called "Dark Age" at the end of the second millennium B.C., but by the eighth-ninth centuries vessels were again being made and are known from Egypt and Mesopotamia. Glass production expanded towards the end of the first millennium B.C. when it was widely traded in the form of beads and hemispherical bowls, in general still strongly coloured. The adoption of blowing in the first century BC and its rapid spread from its origins in Syria-Palestine throughout the Roman Empire, accompanied a major expansion in production. Transparent glass vessels became relatively common and inexpensive commodities and by the mid- to late first century AD strong deliberate colours had largely been replaced by weak "natural" transparent blues and greens, along with glass that was essentially colourless. From this time, the use of blown, transparent glass as for drinking and eating, for storage and for windows, continued throughout the Near East and much of Europe.

While clay-based ceramics have been routinely subjected to elemental analysis to determine provenance for several decades, archaeological glass has proved far less tractable. Substantial databases of major element analyses of glass exist (Brill 1999), but beyond broad technological affiliations, meaningful compositional groupings have been difficult to establish. Where trace element or isotopic data were generated, on the whole, it proved possible to interpret them only in very general terms (e.g. Heyworth \& Hunter 1998; Brill et al. 1999).

Recent advances in glass compositional studies originate partly in improvements in analytical capability, particularly in the ability to analyse small samples, or even to conduct essentially non-destructive analyses. In addition, archaeological discoveries have radically changed our understanding of the organisation of glass production in the past. Whereas at one time it was assumed that the glass material itself was made from silica and alkali in the workshops where the vessels, window panes and beads were fabricated, it is now recognised that raw glass was widely traded, for example as lumps of colourless or naturally coloured glass in the Roman and early medieval periods (Foy et al. 2000), and as ingots of coloured glass in the Late Bronze Age (Nicholson et al 1997; Rehren \& Putsch 1997). The primary workshops that made the raw glass were thus distinct from the secondary workshops that shaped the glass into vessels, and a single primary workshop could supply many secondary workshops, dispersed over a very large area (Gorin-Rosen 2000; Nenna et al. 2000). In the primary workshops glass appears to have been made on a scale of many tonnes in a single firing, as illustrated by the 8 tonne glass slab at Beth She'arim, Israel, probably dated to the early ninth century A.D. (Fig.1; Brill 1967, Freestone \& Gorin-Rosen 1999) and the excavations of seventeen tank furnaces of similar capacity at Bet Eli'ezer, Hadera, Israel, probably dated to the $7-8^{\text {th }}$ C. A.D. (Gorin-Rosen 1995, 2000). Three similar furnaces of 6-7 $7^{\text {th }}$ century A.D. date have been excavated at Apollonia-Arsuf, Israel (Tal et al. 2004) and four 10-11 ${ }^{\text {th }}$ century A.D. furnaces at 


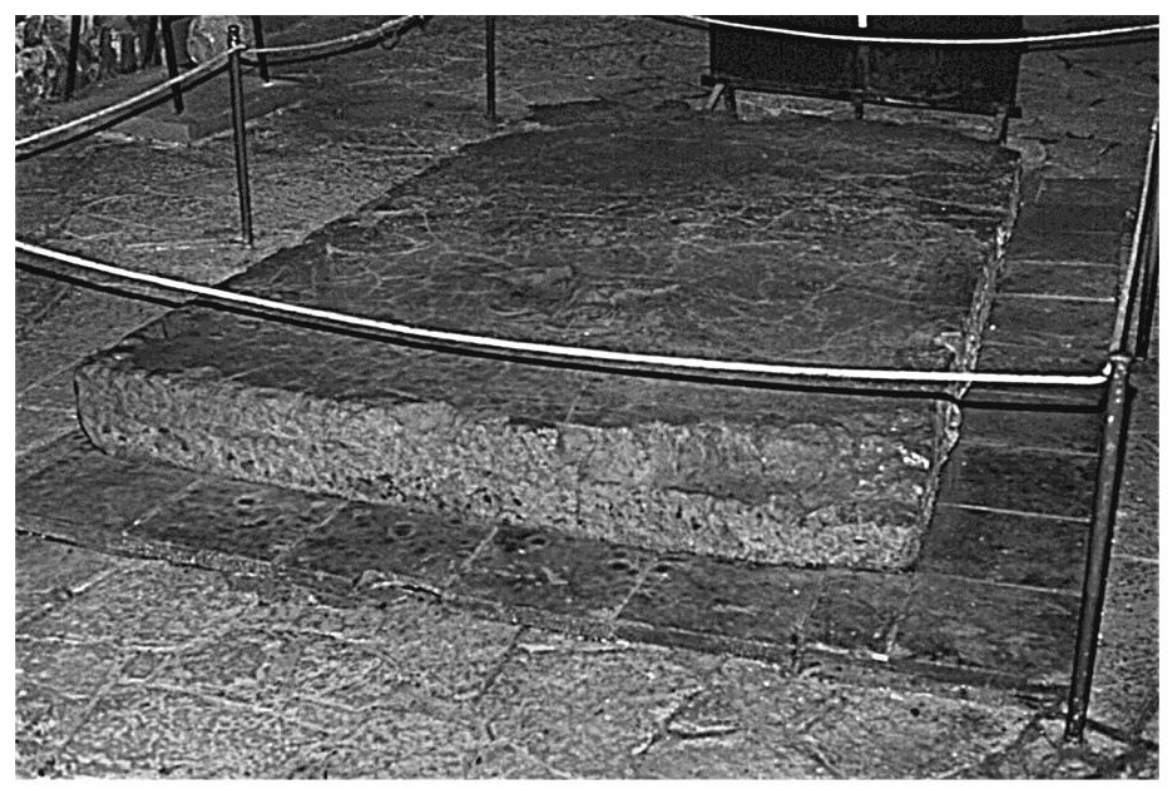

Fig. 1. Large glass slab in a cave at Beth She'arim, Israel. The glass appears to have been melted in situ but was unusable due to excess lime in the batch. Dimensions 3.40 x 1.95 x 0.45 m. Photo: Freestone/Milton.

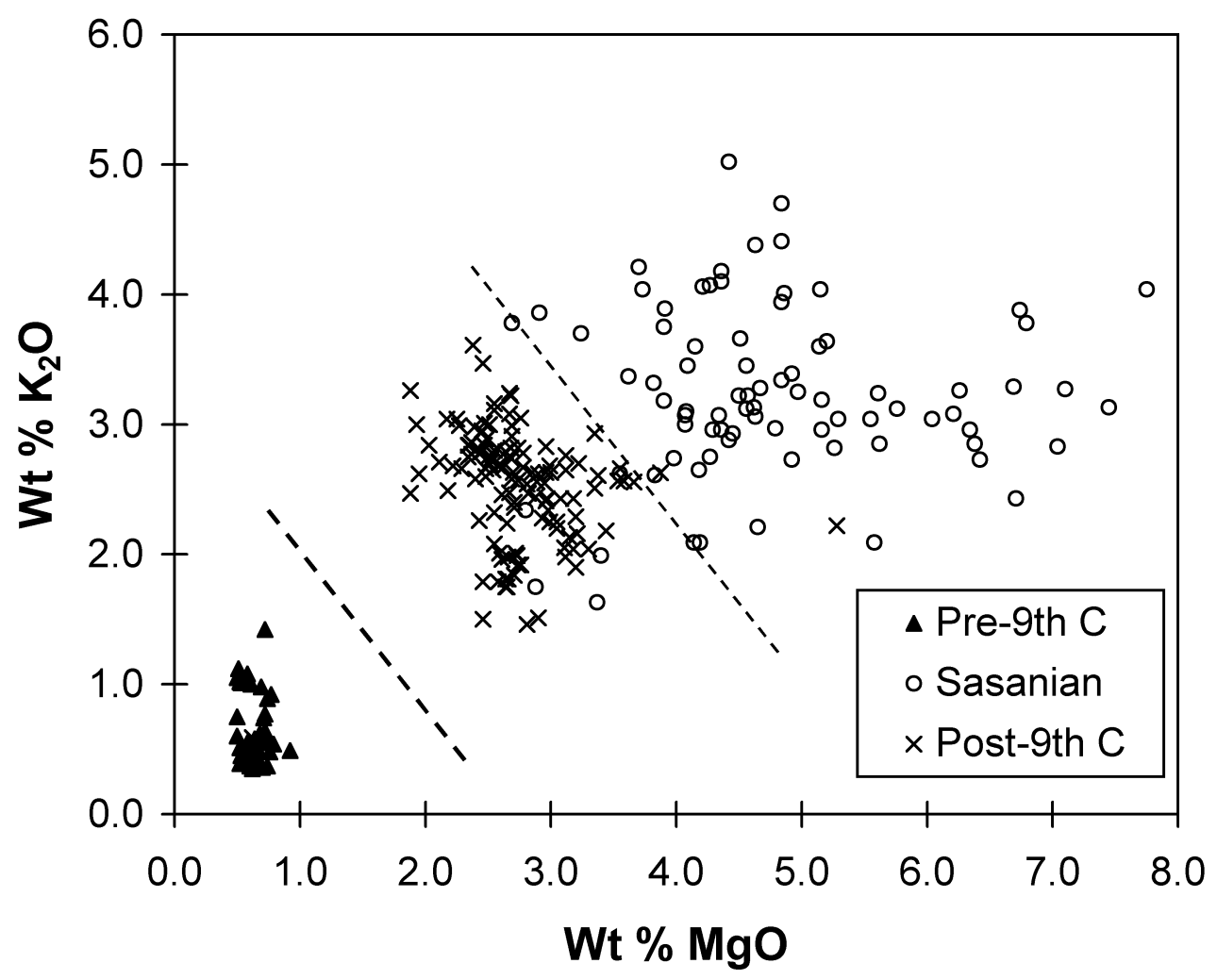

Fig. 2. Compositions of Middle Eastern glasses, showing subdivision between lowmagnesia and high-magnesia glasses. Also shown is the proposed subdivision of high-magnesia glasses into the Sasanian and Syrian-Islamic traditions. Data of Brill 1999, Freestone et al. 2000, Freestone 2002 and Freestone and Leslie (unpublished). 
Tyre, Lebanon, one of which has an estimated capacity in excess of $30 \mathrm{t}$ (Aldsworth et al. 2002).

The concept of a division of production leads to a very different interpretation of analytical data, so that glass compositions reflect predominantly the primary glassmaking sources, rather than the secondary workshops in which the objects were made (e.g. Nenna et al. 1997; Foy et al. 2000; Freestone et al. 2000, 2002a). This new interpretation is leading to an improved understanding of glass production and how it may be investigated using physico-chemical analytical techniques. Informed by an appreciation of the geochemical processes which control the compositions of the raw materials, rapid and significant progress is being made. This is particularly the case for the blown, transparent glass of the Roman period and later. This paper reviews some of the recent work and its implications, focusing in particular upon case studies on glass carried out by the author and collaborators. A summary of the sites and production groups referred to in the text is provided as Table 1.

\section{Categories of glass and sources of soda}

The great majority of ancient glass was based upon silica, fluxed with either soda or potash. Before the medieval period, lead-rich glasses were rare, excepting some strongly coloured opaque glasses and certain glass in the Far East (Brill \& Martin 1991). $\mathrm{K}_{2} \mathrm{O}$-rich glasses are confined largely to medieval Europe, after the tenth century, and to south east Asia, where potash-rich glass beads, probably made in India, were widely traded (Glover \& Henderson 1995). This paper focuses upon soda-lime-silica glasses, which generally lie in the low melting temperature region of the system $\mathrm{Na}_{2} \mathrm{O}-\mathrm{CaO}-\mathrm{SiO}_{2}$ (e.g. Wedepohl 2003). Soda-lime-silica glass is the earliest known from late Bronze Age Mesopotamia and Egypt, in the $2^{\text {nd }}$ millennium B.C., continued as the dominant compositional type across Western Asia and the Mediterranean through to the modern period, and was also important in the glass industries of Renaissance and modern Europe.

In a seminal paper, Sayre \& Smith (1961) observed that ancient soda-lime-silica glasses fell into two main categories: high- $\mathrm{K}_{2} \mathrm{O}$, high- $\mathrm{MgO}$ glass, with greater than about $1.5 \%$ of each of these oxides, and low- $\mathrm{K}_{2} \mathrm{O}$, low- $\mathrm{MgO}$ glass, typically with less than $1.5 \%$ of each oxide. Although exceptions and intermediate compositions are now recognised, this general sub-division is still regarded as a useful one in that it corresponds to the use of the two principle soda-rich fluxes available in the ancient world. Table 2 provides some examples of these glass types and data are plotted in Fig. 2 to illustrate how glass from Late Antiquity and the early Islamic period in the Middle East may be divided into the two groups. Since the original work, it has become generally accepted that these two glass groups correspond to the use of two principal sources of soda - evaporitic minerals and plant ash.

Evaporites rich in sodium bicarbonate were available from Egypt and possibly other locations (Shortland 2004; Shortland et al., in press), where they are precipitated as saline lakes begin to evaporate in the spring. The Egyptian deposits, known mainly today from the Wadi Natrun, about $100 \mathrm{~km}$ north west of Cairo, but also from alBarnuj in the Western Delta (Fig. 3), comprise predominantly one or more of the minerals trona, thenardite, burkeite and halite. References to the extraction of soda 
Table 1. Summary information on sites and assemblages mentioned in the figures and text

\begin{tabular}{|c|c|c|c|c|c|}
\hline Find Site/or group & $\begin{array}{l}\text { Probable primary source } \\
\text { areas/groups }\end{array}$ & Period A.D. & Context & $\begin{array}{l}\text { Glass } \\
\text { Type }\end{array}$ & Glass form \\
\hline Leicester, UK & ?Levantine & $1^{\text {st }}-3^{\text {rd }} \mathrm{C}$ & Consumer site & Natron & Vessel fragments \\
\hline Bet Eli`ezer, Israel & Bet Eli'ezer, Israel & $7^{\text {th }}-8^{\text {th }} \mathrm{C}$ & Primary furnaces & Natron & Raw glass chunk \\
\hline Bet She'an, Israel & Syria-Palestine & $6^{\text {th }}-7^{\text {th }} C$ & Secondary workshop & Natron & Raw glass chunk \\
\hline Apollonia (Arsuf), Israel & Apollonia, Israel & $6^{\text {th }}-8^{\text {th }} C$ & $\begin{array}{l}\text { Primary and secondary } \\
\text { workshops }\end{array}$ & Natron & $\begin{array}{l}\text { Raw glass chunk and } \\
\text { vessel fragments }\end{array}$ \\
\hline North Sinai & HIMT (?Egypt) and Levantine & $4^{\text {th }}-5^{\text {th }} \mathrm{C}$ & Field survey & Natron & Vessel fragments \\
\hline Maroni Petrera, Cyprus & HIMT (?Egypt) and Levantine & $6^{\text {th }}-7^{\text {th }} C$ & Church & Natron & Vessel and window \\
\hline Tel el-Ashmunein, Egypt & Egypt II (?Middle Egypt) & $8^{\text {th }}-9^{\text {th }} \mathrm{C}$ & Secondary workshop & Natron & Vessels and waste \\
\hline Jarrow, UK & Syria-Palestine & $7^{\text {th }} \mathrm{C}$ & Monastery & Natron & Window fragments \\
\hline Beth Shea'rim, Israel & Bet Shea'rim, Israel & $? 9^{\text {th }} \mathrm{C}$ & Primary furnace & Plant ash & Large slab \\
\hline Banias, Israel & ?Syria-Palestine & $10^{\text {th }} / 11^{\text {th }}-13^{\text {th }} \mathrm{C}$ & Secondary workshop & Plant ash & Raw glass chunk \\
\hline Nineveh, Iraq & ?Mesopotamia & $4^{\text {th }}-7^{\text {th }} C$ & Consumer site & Plant ash & Vessel fragments \\
\hline Tyre, Lebanon & Tyre Lebanon & $10^{\text {th }} / 11^{\text {th }} \mathrm{C}$ & Primary furnaces & Plant ash & Raw glass chunk \\
\hline Raqqa, Syria & Raqqa, Syria & $8-9^{\text {th }} \mathrm{C}$ & Workshop complex & Plant ash & Chunk and vessel \\
\hline Ras al Hadd, Oman & unknown & $11^{\text {th }}-14^{\text {th }} \mathrm{C}$ & Consumer site & Plant ash & Vessel fragments \\
\hline
\end{tabular}


Table 2. Major element compositions of selected soda-lime-silica glasses

\begin{tabular}{|c|c|c|c|c|c|c|}
\hline Oxide & $\begin{array}{l}\text { Blue-green } \\
\text { Leicester }^{1}\end{array}$ & $\begin{array}{c}\text { HIMT } \\
\text { North Sinai }^{2}\end{array}$ & $\begin{array}{c}\text { Levantine } \\
\text { Beth Shean }\end{array}$ & $\begin{array}{c}\text { Levantine } \\
\text { Bet Eli'ezer }\end{array}$ & $\begin{array}{c}\text { Plant ash } \\
\text { Banias }^{4}\end{array}$ & $\begin{array}{l}\text { Plant ash } \\
\text { Nineveh }^{5}\end{array}$ \\
\hline $\begin{array}{c}\text { Cultural } \\
\text { period }\end{array}$ & Roman & Late Roman & Byzantine & Early Islamic & Early Islamic & Sasanian \\
\hline Date & $1-3^{\text {rd }}$ C A.D. & 4-5 ${ }^{\text {th }}$ C A.D. & 6- $7^{\text {th }}$ C A.D. & 7-8 ${ }^{\text {th }}$ C A.D. & $10-13^{\text {th }}$ C A.D. & 4-7 $7^{\text {th }}$ C A.D. \\
\hline$N$ & 75 & 18 & 17 & 27 & 17 & 19 \\
\hline $\mathrm{SiO}_{2}$ & NA & 65.8 & 69.3 & 74.9 & 70.5 & 63.2 \\
\hline $\mathrm{Al}_{2} \mathrm{O}_{3}$ & 2.33 & 2.69 & 3.03 & 3.32 & 1.06 & 2.70 \\
\hline $\mathrm{FeO}$ & 0.60 & 2.18 & 0.45 & 0.52 & 0.40 & 0.93 \\
\hline $\mathrm{MnO}$ & 0.26 & 1.51 & $<0.1$ & $<0.1$ & 1.00 & 0.08 \\
\hline $\mathrm{MgO}$ & 0.55 & 0.94 & 0.59 & 0.63 & 2.72 & 4.49 \\
\hline $\mathrm{CaO}$ & 6.43 & 5.99 & 9.17 & 7.16 & 8.55 & 7.57 \\
\hline $\mathrm{Na}_{2} \mathrm{O}$ & 18.4 & 18.0 & 15.6 & 12.1 & 12.5 & 16.5 \\
\hline $\mathrm{K}_{2} \mathrm{O}$ & 0.69 & 0.46 & 0.63 & 0.46 & 1.89 & 3.23 \\
\hline
\end{tabular}

Sources of data: 1. Jackson et al. 1991; 2. Freestone et al. 2002b; 3. Freestone \& Gorin-Rosen, unpublished;

4. Freestone et al., 2000; 5. Freestone \& Leslie, unpublished. 
from Wadi Natrun are found in the ancient and medieval literature and al-Barnuj appears to have been referred to as a source of natron in the fourth century A.D. (Shortland et al, in press). Furthermore, several primary glassmaking sites are known in the Wadi Natrun (Nenna et al. 2005). The trona-rich varieties are considered to have been preferred for glassmaking, because sulphates and chlorides do not readily decompose and react with silica at the temperatures of $1000-1200^{\circ} \mathrm{C}$ that are likely to have been attainable in traditional glassmaking furnaces. Traditionally, in archaeology and Egyptology, these salts are commonly known as natron; however, to avoid confusion with the mineral of that name, in the present paper they will be referred to as mineral soda.

It is unlikely that glassmakers restricted themselves to the use of pure trona. Virtually all glass of this period contains $0.5-1.2 \% \mathrm{Cl}$ and $0.2-0.5 \% \mathrm{SO}_{4}$, which are likely to have been close to the solubilities of these components in the glass when it was made (e.g. Bateson \& Turner 1939). The sulphur and chlorine in the glass are likely to have been derived from the alkali. It is probable that the excess sodium chloride and sulphate separated as an immiscible "scum" or "gall" on the surface of the freshly melted glass, which could be skimmed off or discarded after the glass had cooled. Evidence of an immiscible sodium sulphate phase in ancient glass has been reported by Stapleton \& Swanson (2002), while Barber \& Freestone (1990) report the subliquidus (metastable) phase separation of sodium chloride, suggesting that the glass was near saturation at the working temperature. Egyptian mineral soda is typically low in cations other than $\mathrm{Na}^{+}$(Brill 1999; Shortland 2004) and added few impurities to the glass batch. Its use gave rise to the low- $\mathrm{MgO}, \mathrm{low}-\mathrm{K}_{2} \mathrm{O}$ compositional category of glass identified by Sayre and Smith (op. cit.). These glasses are frequently termed "Roman-type" or "natron" glasses. In the following, they will be referred to as lowmagnesia glasses.

The second sodic flux available to early glassmakers was the ash produced by burning halophytic plants, for example salicornia and salsola sp. from semi-arid and coastal environments. The harvesting of plants to produce ashes has a long history in all parts of the world, and they were used for medicinal purposes and in the production of detergent, as well as for glass making (Ashtor \& Cevidalli 1983). In addition to soda, such plant ashes contain high levels of lime, as well as magnesia, potash, phosphate and some silica and other components (Brill 1970; Verità 1985). The glasses formed by mixing soda ash with a source of silica are richer in impurities than those produced from mineral soda, and form the high- $\mathrm{MgO}$, high- $\mathrm{K}_{2} \mathrm{O}$ compositional category.

In the period of interest, low-magnesia glass was generally used west of the Euphrates and plant ash glass was used to the East for most of the first millennium A.D. (Smith 1963). As shown in Fig. 2, there was a switch from the use of mineral soda to plant ash flux in western regions from the middle of the ninth century A.D. (Gratuze \& Barrandon 1990), probably due to political upheavals in the Delta region (Whitehouse 2002; Shortland et al. in press). From this time, the majority of soda-lime-silica glasses were of the high-MgO, high- $\mathrm{K}_{2} \mathrm{O}$ type.

An additional subdivision of the high-magnesia (plant ash) group may usefully be recognised. The plant ash glasses from the Syria-Palestine region have compositions with $\mathrm{K}_{2} \mathrm{O}$ and $\mathrm{MgO}$ of 2-3.5\% (e.g. from the Serce Limani wreck, Brill 1999; Banias, Freestone et al. 2000; and Tyre, Freestone 2002). However, plant ash glasses made up 
to the seventh century A.D. to the East of the Euphrates, in the region of the Persian Empire under the Parthians and Sasanians, tend to have $\mathrm{MgO}$ and $\mathrm{K}_{2} \mathrm{O}$ contents greater than $3.5 \%$ (Fig. 2). This appears to indicate a difference in raw materials and/or technology, possibly in the species of plants that were ashed for glassmaking. It may speculatively be suggested that the Partho-Sasanians were exploiting plants from a particular environment, for example the salt marshes in the South of presentday Iraq, which conferred a different composition to Syrian plant ashes.

Alternatively, the high $\mathrm{MgO}$ in the Sasanian glass may reflect the $\mathrm{MgO}$-rich alluvium of the Euphrates and the Tigris which, from the analysis of ceramic bodies made from it appears to have a relatively high $\mathrm{MgO} / \mathrm{CaO}$ ratio (e.g. Freestone 1991).

A difficulty in resolving this issue is that our understanding of the manufacture of plant ash glass is very limited. Plant ash is a very variable raw material, its composition varying according to species, environment, and even the part of the plant that is harvested. However, as has been emphasised by Rehren (2000) this variable and apparently unpredictable material was used to produce glass of a relatively restricted compositional range at any one place and time. How compositional control was maintained is not clear, and neither is the relationship between the compositions of the plants, the ashes and the final glasses. Careful selection of plant material, discard of poor quality glass (Freestone 2002) and the melting process itself (Shugar $\&$ Rehren 2002) are all likely to have played a part in the process of compositional control.

It may be that our understanding of the production of plant ash glass is hindered by the very scale on which it occurred. From the perspective of the modern laboratory analyst, it is very difficult to obtain a sample of plant ash which is representative of the hundreds of kilograms that would have been added to a single batch of raw glass. Processing plant material on this scale may have resulted in a homogenisation of this variable raw material towards an average composition which cannot be recognised in modern samples of individual plants or parts of plants.

\section{Silica sources}

Potential sources of silica include quarried siliceous minerals and rocks such as vein quartz, chert and quartzite, as well as pebbles of these materials and sand. It seems likely that, over much of the period and region under consideration here, sand was the preferred source of silica, as to mine and crush silica on a scale of tonnes for each firing would have been very costly. Some direct evidence for this is observed from the waste products of glass furnaces where the reaction did not proceed to completion. For example, a large block of glassy material from one of the Islamic period furnaces at Tyre, Lebanon contains patches of silica 5-10 $\mathrm{mm}$ across and readily visible with the naked eye (Aldsworth et al. 2002). In the microscope, these patches are seen to be aggregates of fine-grained quartz sand particles, which represent the siliceous raw material (Fig. 4). The glass made at Tyre has an $\mathrm{Al}_{2} \mathrm{O}_{3}$ content of around $1.8 \%$ and $\mathrm{Fe}_{2} \mathrm{O}_{3}$ of $0.5 \%$; even assuming that all of these components derived from the sand, it appears that the sand was mature and composed of around $95 \%$ quartz. On the other hand, Henderson et al. (2005) present evidence for the use of crushed quartz pebbles as a silica source in the production of Islamic period plant ash glass at elRaqqa, Syria. The el-Raqqa glasses are characterised by lower $\mathrm{Al}_{2} \mathrm{O}_{3}$ contents than 


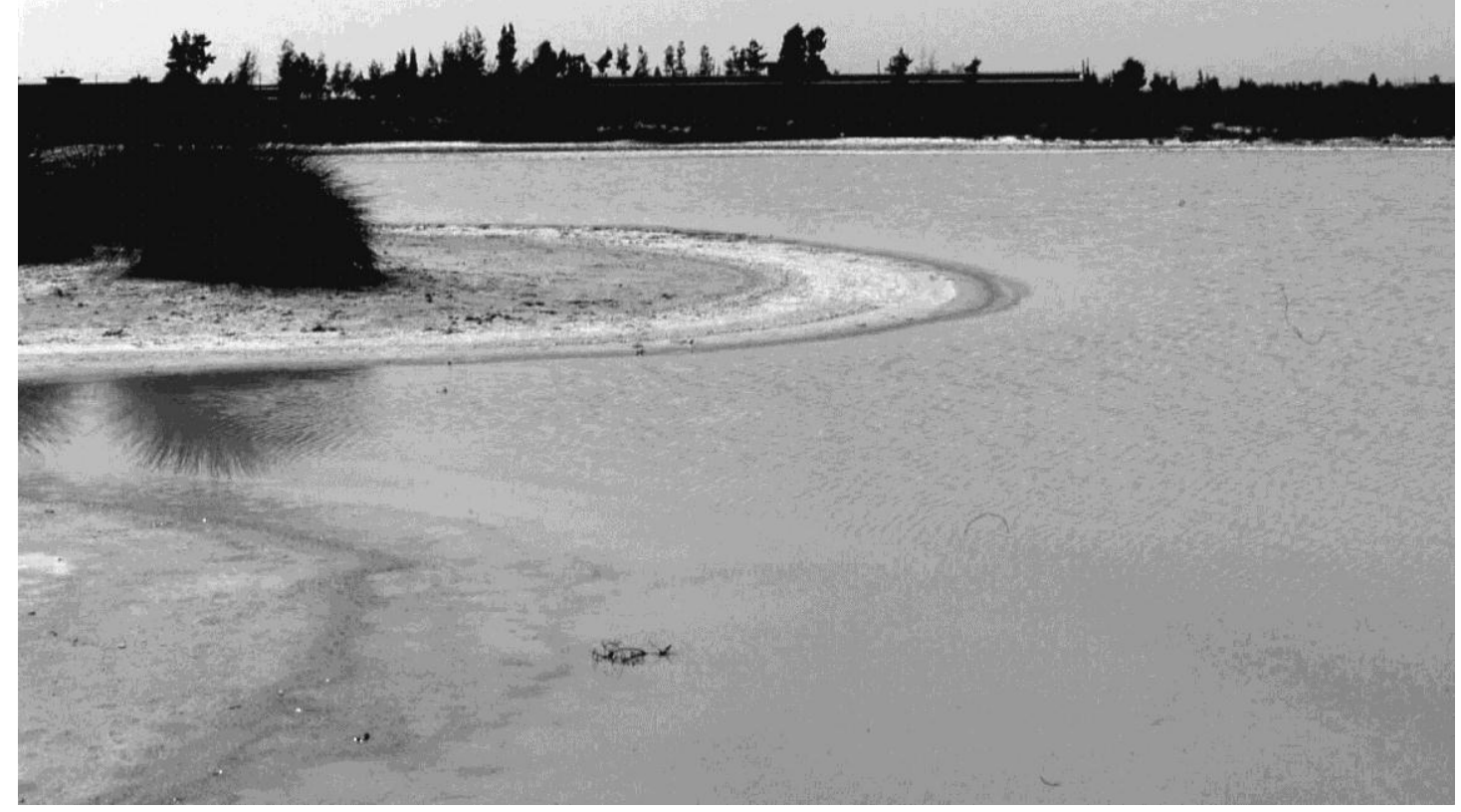

Fig. 3. Trona precipitating at the edge of a lake at al-Barnuj, Nile Delta, April 2004. Photo: I Freestone

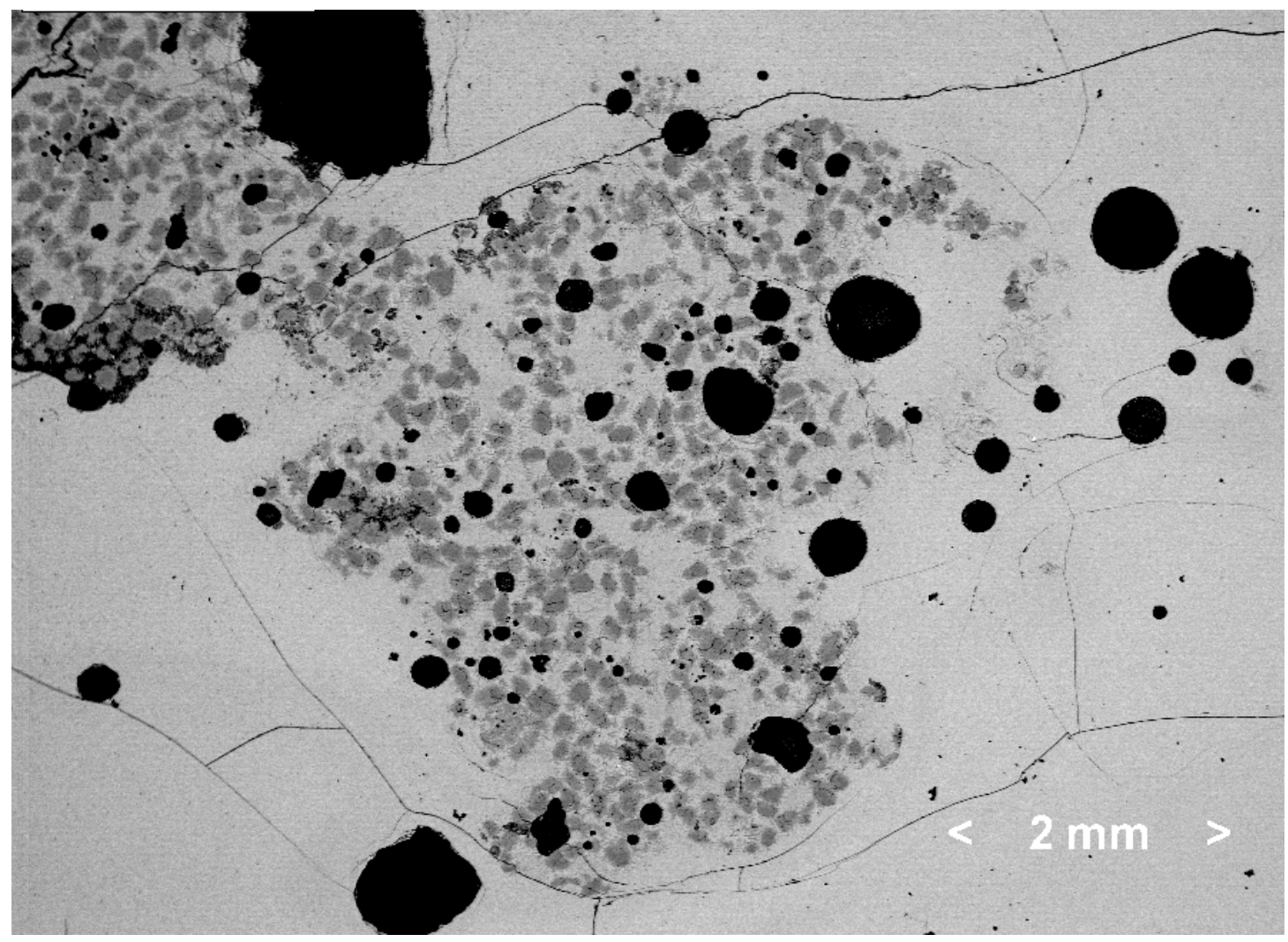

Fig. 4. Back-scattered electron image showing quartz sand particles in partially fused, vesicular glass from a primary tank furnace at Tyre, Lebanon. 
those of Tyre (Freestone 2002) due to the relatively pure nature of quartz pebbles relative to a feldspar-bearing sand. A group of Islamic glasses from Nishapur were considered to have been made using pebbles by Brill (1995), for similar reasons.

Further evidence for the use of sand as a starting material comes from Pliny the Elder, who wrote his Natural History in around 70 A.D.. Pliny's is the only surviving written account of Roman glass production and indicates that, for many years, glass making had depended upon a mixture of Egyptian soda with the sand from beach near the mouth of the River Belus, on the coast of Syria:

This is supposed to be the source of the River Belus, which after traversing a distance of 5 miles flows into the sea near the colony of Ptolemais..... The beach stretches for not more than half a mile, and yet for many centuries the production of glass depended on this area alone....... (NH XXXVI, 190; Eicholz 1962).

The Belus is the present-day River Naaman, which flows into the Bay of Haifa and it is from the beach near the mouth of the river that Pliny indicates the glassmaking sands were obtained. The sediments of the coast of Israel are derived from the Nile, and are moved up the coast by the prevailing Mediterranean current and longshore drift. For a general sedimentary model, see Goldsmith \& Golik (1980) and Stanley et al (1997). They contain calcium carbonate in the form of marine shell and limestone eroded from the kurkar cliffs. Emery \& Neev (1960) determined calcium carbonate contents and colours for sands for a series of beach stations spanning the coast of modern Israel. In order to understand the reasons for the selection of the glassmaking sand, their data are plotted in Fig. 5. The two curves show weight percent $\mathrm{CaCO}_{3}$ and Munsell colour saturation versus location (beach station). The lower the colour saturation, the paler is the sand. The figure shows that the sand from beach stations 28 and 29, situated in the Bay of Haifa, are among the palest on the coast. This implies relatively low iron oxide contents for these sands, so that they would make relatively pale or weakly coloured glasses. In addition the calcium carbonate content of sand in the Bay of Haifa is around $15 \%$, which would produce a soda-lime-silica glass with $8-9 \% \mathrm{CaO}$. This is around the level required to produce a stable and workable glass. Thus it appears that sand close to the mouth of the River Belus was the most suitable glass-making sand on this part of the Mediterranean coast, and was deliberately selected by Roman glassmakers for this reason. A detailed comparison of the chemistry of sand from the mouth of the River Belus and glass from a fourth century A.D. glass workshop in Israel was conducted by Brill (1988).

It is unlikely that beach in the vicinity of the Belus was the only source of glassmaking sand. The presence of primary glassmaking installations further down the Levantine coast, at Apollonia-Arsuf (Tal et al. 2004) and Bet Eli'ezer, Hadera (Gorin-Rosen 2000), as well as in Egypt (Nenna et al. 1997, 2000) suggests that other sands in the eastern Mediterranean region were suitable for this purpose. Intriguingly, much of the evidence in the Levant relates to the Islamic period, and the factory (or factories) that produced the bulk of Roman glass is yet to be discovered. Pliny also remarks that sand between Cumae and Literno, on the coast of Italy (about $50 \mathrm{~km}$ north of Naples) was used to make glass, and that "sand is similarly blended in the Gallic and Spanish provinces" (Eicholz op. cit.). However, direct archaeological evidence for primary glass production in these regions has not been found to date. 


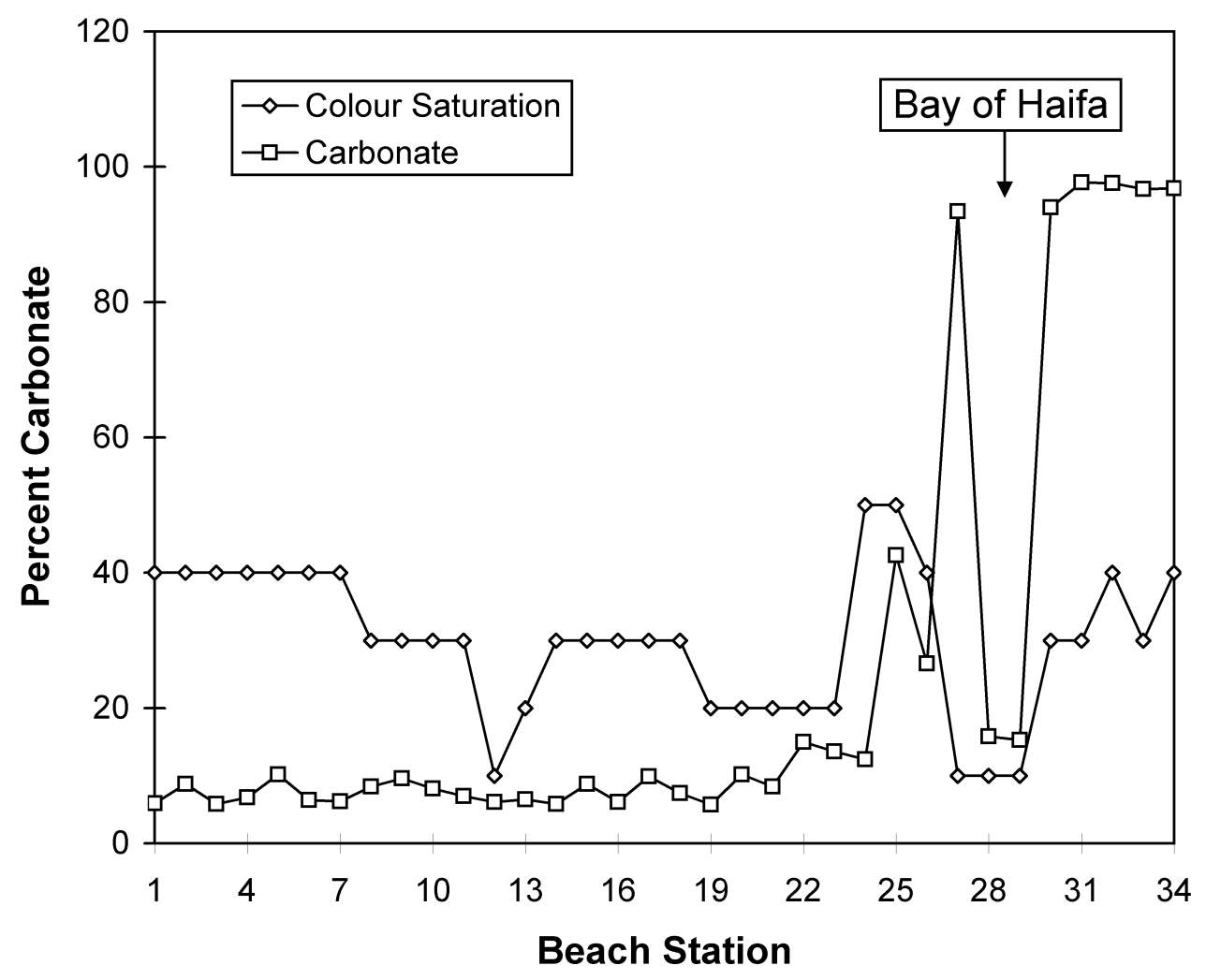

Fig. 5. Colour saturation (arbitrary scale) and carbonate content of beach sands from the coast of present day Israel. Data from Emery and Neev (1960).

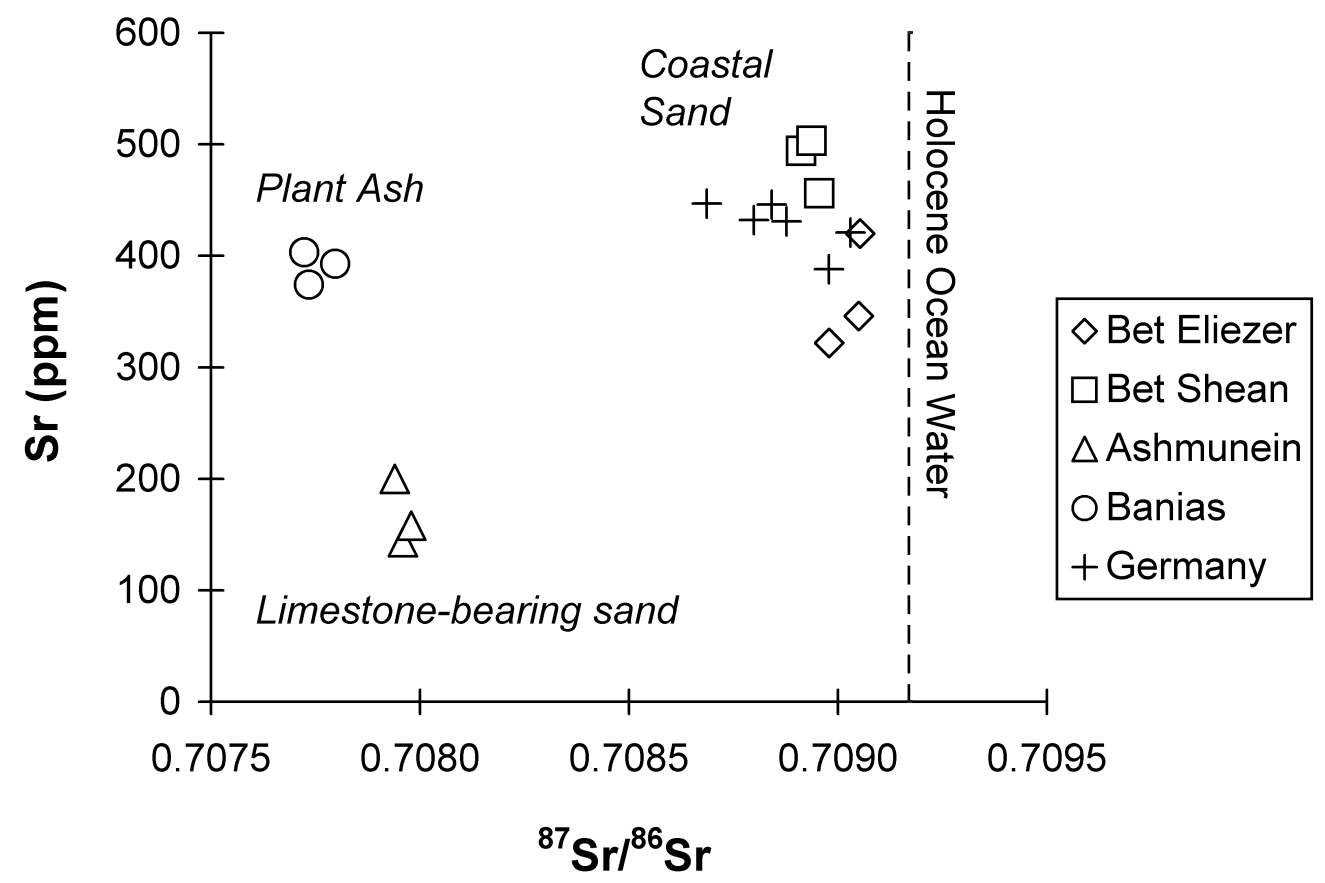

Fig. 6. Strontium isotopes and total strontium in glasses from the Near East and Germany (Freestone et al. 2003, German data from Wedepohl and Baumann 2000). 


\section{Strontium and Sources of Lime}

Lime, typically present at levels of 5-10\% (Table 2), is a desirable component of glass as it reduces its solubility in water, so that it is environmentally stable. Plant ash contains both alkali and lime and it is not necessary to invoke extra additions of lime to explain the compositions of plant ash glasses (Freestone \& Gorin-Rosen 1999). However, mineral soda contains essentially no lime, and the source of lime in lowpotash, low-magnesia glasses must be sought elsewhere.

There are essentially two models for the origin of lime in low-magnesia glass. Lime may have been added deliberately to the batch by the glassmakers, to a fixed recipe, to produce a glass of consistent properties. This model is supported by a comment of Pliny, who mentions shell in a list of materials that could be added to glass. This explanation has the clear advantage of explaining why so much blue-green Roman glass of the first-third centuries A.D. is of a remarkably constant composition. The second model explains the lime content of low-magnesia glass as deriving from particles of shell or limestone in the sand used as the source of silica, the sands of the Levantine coast (Fig. 5) being the classic example. Once again, this model is supported by Pliny, who specified the lime-bearing Belus sand for glass making. The two models for the origin of lime are not mutually exclusive, as glassmakers may have exploited lime-bearing sands where available, and added crushed shell or limestone to pure quartz sand where they were not.

A solution to the question of the origin of lime was offered by Wedepohl \& Baumann (2000), who pointed out that most strontium Roman glass was likely to have entered the batch in calcium-rich minerals, in particular calcite and aragonite. Late Roman ( $4^{\text {th }}$ century) glass from the Rhineland analysed by them had high $\mathrm{Zr}$ and $\mathrm{Ba}$, consistent with local river sediments, as well as lead isotopes consistent with the ores of the region. This led them to suggest that the glasses were made locally, using local river sand as a source of silica. To determine the form in which the lime was added to the glass they measured the concentrations of strontium and its isotopes. The glasses have relatively high strontium/calcium ratios, appropriate to marine biogenic carbonate rather than limestone which has undergone diagenesis. Furthermore, ${ }^{87} \mathrm{Sr} /{ }^{86} \mathrm{Sr}$ ratios of around 0.7090 , close to modern seawater $\left({ }^{87} \mathrm{Sr} /{ }^{86} \mathrm{Sr}=\sim 0.7092\right)$, also suggest that the lime was derived from shell. Thus they conclude that their glass was made using local sand to which shell was deliberately added to give the appropriate amounts of lime.

Freestone et al. (2003) measured strontium isotopes in low-magnesia glasses from the primary tank furnaces at Bet Eli'ezer, near Hadera on the Levantine coast. They are shown with a number of other glass groups, including the Rhenish glasses of Wedepohl \& Baumann (2000), in Fig. 6. These glasses are believed to have been made utilising the nearby coastal sands which naturally contain calcium carbonate in the appropriate concentrations to yield good soda-lime-silica glass (Fig. 5). The data show that the Levantine glasses have ${ }^{87} \mathrm{Sr} /{ }^{86} \mathrm{Sr}$ and total $\mathrm{Sr}$ similar to the Rhenish glasses. As might be expected, glass made from sand which contains intrinsic shell has similar strontium characteristics to glass to which shell has been deliberately added. Thus the strontium approach, while indicating the mineralogy of the added lime, cannot determine whether it was deliberately added. The case for deliberate addition of shell to the Rhenish glasses rests upon the inference that their trace 
element and lead isotope compositions imply a local origin. However, Freestone et al. (2005) have shown that a category of fourth century glass termed HIMT (see below), which occurs widely in Europe and the Mediterranean, has similar isotopic and trace element compositions to the Rhenish glass analysed by Wedepohl \& Baumann (op. cit.). Given the $4^{\text {th }}$ century dates of all of these glasses, it seems probable that they have a single origin and that the Rhenish glasses are unlikely to have been locally made.

The preferred interpretation of the author follows that expressed by Brill (1986) in that lime was rarely deliberately added as a separate component in ancient glassmaking and that glass was widely made as a mixture of just two components, silica and flux. Where the flux was ash, a lime-free silica source was used. Where the flux was mineral soda, a calcareous quartz sand was used. In each case, the appropriate mixture of silica and flux gave glass with similar $\mathrm{Na}_{2} \mathrm{O}: \mathrm{CaO}: \mathrm{SiO}_{2}$ ratios. Rarely, soda ash and calcareous sand were combined to give a glass with lime from two sources. For example, the glass slab at Beth She'arim (Fig. 1) seems to have been produced in this way and, due to the resultant $15.9 \% \mathrm{CaO}$, devitrified to wollastonite (Brill 1967; Freestone and Gorin-Rosen 1999). Note that glasses from tank furnaces with "normal" $\mathrm{CaO}$ contents, less than $10 \%$, are not normally devitrified in this way (Freestone et al. 2000; Freestone 2002; Tal et al. 2004), so that the archaeologically significant variable here is composition, not cooling rate; although a slow cooling rate is required to cause the glass to devitrify, the cooling rates of these installations are likely to have been very similar.

The selection of an appropriate glassmaking sand can have a critical effect on the preservation of glass in the archaeological record. On the basis of the limited evidence from recovered glasses, it appears that, when Egyptian mineral soda began to be used on a large scale in glassmaking around the $10^{\text {th }}-8^{\text {th }}$ centuries B.C., glasses were frequently made using vein quartz or sand with insufficient lime to render them stable over archaeological time. Most of these are likely to have dissolved away, leaving limited evidence of this important technological change (Reade et al. 2005).

Assuming the foregoing model for the origin of the lime, then the remaining data in Fig. 6 are readily explained. The low levels of strontium and low ${ }^{87} \mathrm{Sr} /{ }^{86} \mathrm{Sr}$ in lowmagnesia glass from an eighth to ninth century A.D workshop at Tell el-Ashmunein, in middle Egypt, represents the use of an inland sand containing clasts of limestone, rather than shell. The strontium in the glass from Banias, was derived from plant ash, and reflects the bioavailable material in the soil in which the ashed plants which grew. It therefore and has a terrigenous isotopic signature and a relatively high strontium content which reflects the strontium capacity of the minerals in the plant structure, which are likely to have included calcium oxalates (Freestone et al. 2003).

\section{Provenancing low-magnesia glass}

As low-magnesia glass is essentially a mixture of soda and sand, and the evaporites of the Wadi Natrun and the Delta are relatively pure soda sources, the question of the provenance of glass is reduced in essence to that of slightly diluted sand. In this paper, by the term provenance is understood the place where the raw glass was made, not the place where it was shaped, which could have been very different. 
Lime and alumina concentrations reflect those in the raw material and may be used to provide an initial impression of glass groups. Fig. 7 shows five commonly-occurring glass groups, dating from the $4^{\text {th }}-9^{\text {th }}$ centuries A.D. Egypt II and Wadi Natrun, appear to reflect Egyptian manufacture between $7^{\text {th }}$ and $9^{\text {th }}$ centuries (data of Gratuze and Barrandon 1990), Bet Eli'ezer and Levantine I represent different productions on the Levantine coast (Freestone et al. 2000) and HIMT has been tentatively attributed to a late Roman primary production in Egypt (Freestone et al. 2005). These groupings are largely a reflection of calcium carbonate and feldspar minerals in the sand used to make the glass. It appears that at any one time glass was being made in a limited number of localities. Multivariate statistical analysis of compositional data for lumps of raw glass from shipwrecks and workshops along with typologically wellcharacterised vessels has allowed Foy, Picon and co-workers (2000, 2003a, b) to identify ten distinctive low-magnesia glass groups in use in the Mediterranean region in the first millennium A.D., on the basis of their major element composition. Each group is assumed to relate to a primary production centre, although such a centre may consist of more than one factory in a single region. For example, the products of the Levantine coast (Belus-type sand) are grouped together, although individual workshops may have slightly different chemical characteristics (Fig. 7).

Mean concentrations of selected trace elements in low-magnesia glasses from Byzantine-Islamic (6-9 $9^{\text {th }}$ centuries) workshops at Bet Eli'ezer (near Hadera) and Apollonia (Arsuf) on the coast of Israel are shown in Fig. 8, normalised to crustal values (Freestone et al. 2000). These samples are mainly of primary glass and show a consistent pattern. This is to be expected, as the glasses were made from Levantine coastal sand of which the major component was ultimately derived from the Nile, as discussed above. The heavy mineral assemblages of the beach and dune sands from this region are similar and are dominated by hornblende (Emery \& Neev 1960; Pomerancblum 1966). The trace elements in the Levantine glasses reflect this relatively homogeneous raw material. This characteristic trace element distribution may be contrasted with that of the glass from the workshop at Tel el-Ashmunein, Egypt, which was shown by strontium isotope analysis to have been made using inland sand (see above). The el-Ashmunein glass (Fig. 8) differs from the Levantine glasses in terms of the concentration of elements such as $\mathrm{Zr}$ and $\mathrm{Ba}$, in addition to the lower $\mathrm{Sr}$ which is a reflection of the presence of limestone, rather than shell, in the sand (Freestone et al. 2000, 2003).

These and other differences in trace element composition (see also Freestone et al. 2000) suggest that it should be possible to source glass by elemental analysis. This possibility was investigated using vessel glass from Maroni Petrera, a 6-7 $7^{\text {th }}$ century A.D. Byzantine church on the southern coast of Cyprus, which faces the Levantine coast and therefore could be expected to have obtained raw glass material from this region. Two compositional groups were identified on the site (Freestone et al. 2002a). A good match was found between the major and trace elements of the glass from the larger of these groups and glass from the Levantine workshops (Fig. 9; Freestone et al. 2002a), consistent with the inferred origin in Syria-Palestine.

It should be noted that the comparison between the primary furnaces and the Cypriot glass neglected the transition metals associated with glass colouration, which are substantially higher in the vessels (Fig. 10). This is the result of recycling old glass, 


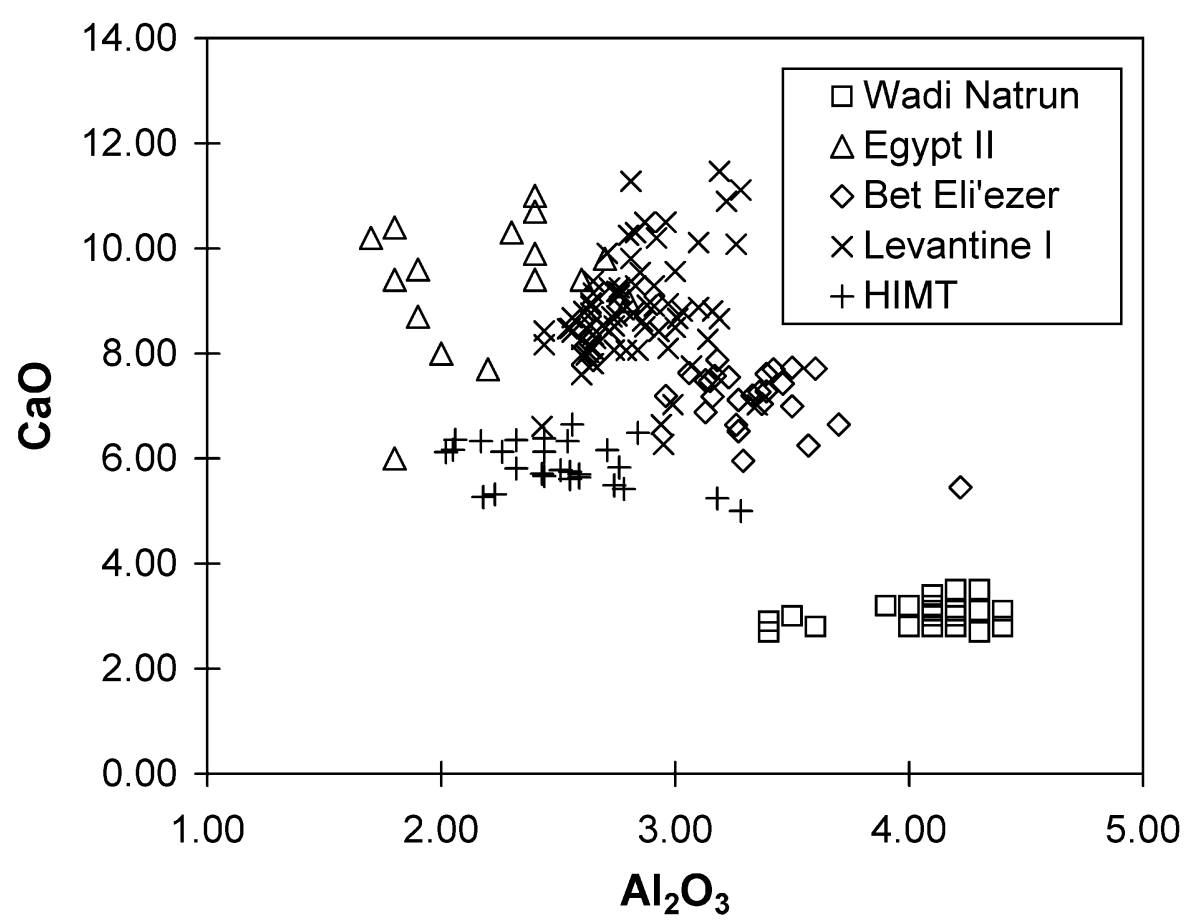

Fig. 7. Lime and alumina contents of a number of glass groups.

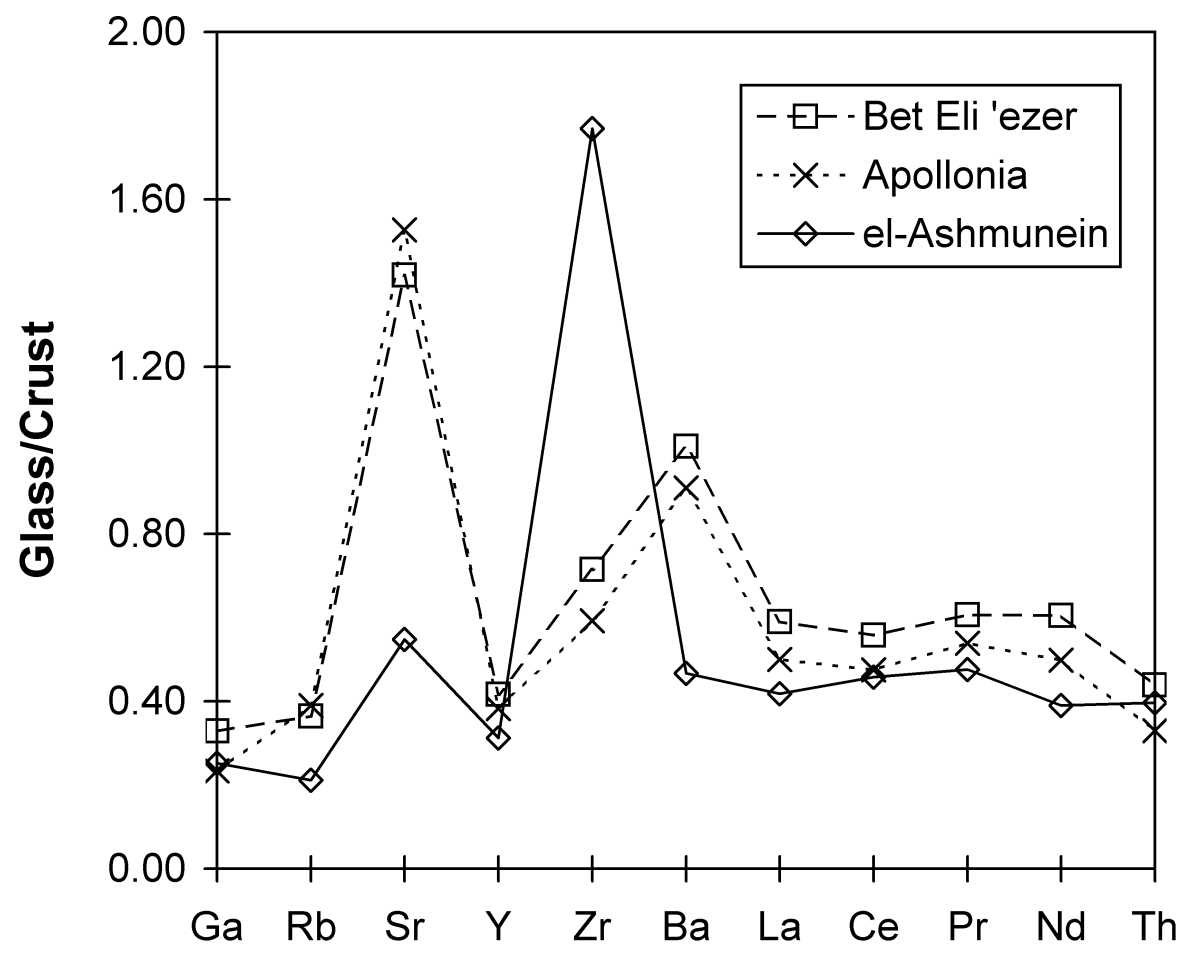

Fig. 8. Trace elements, normalised to mean crustal composition, for Levantine primary glass from Bet Eli'ezer $(\mathrm{n}=5)$ and Apollonia $(\mathrm{n}=5)$ compared with a workshop at el-Ashmunein, middle Egypt (Freestone et al. 2000). 


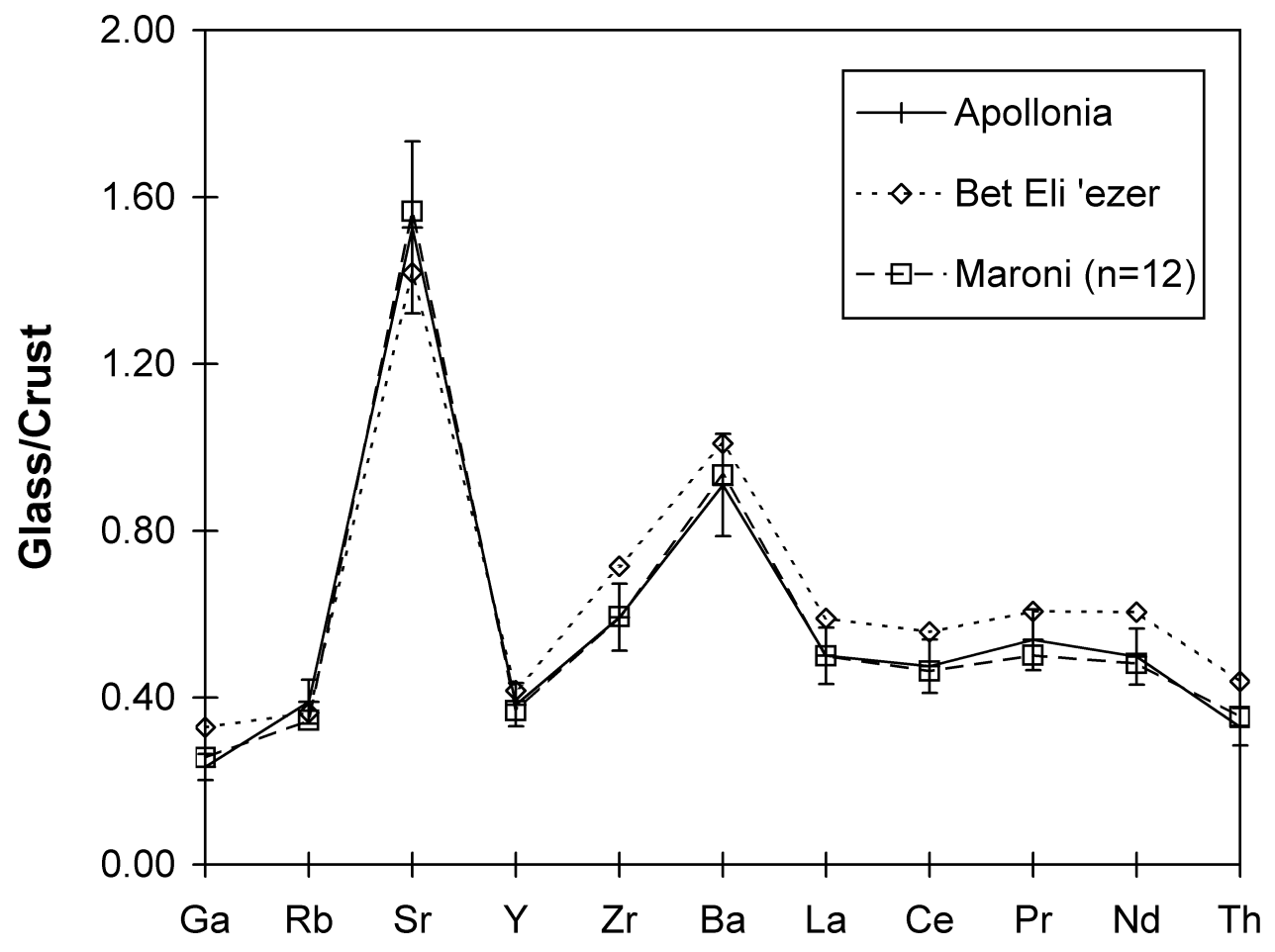

Fig. 9. Mean trace element concentrations for 12 glasses from Maroni Petrera compared to those from Levantine tank furnaces.
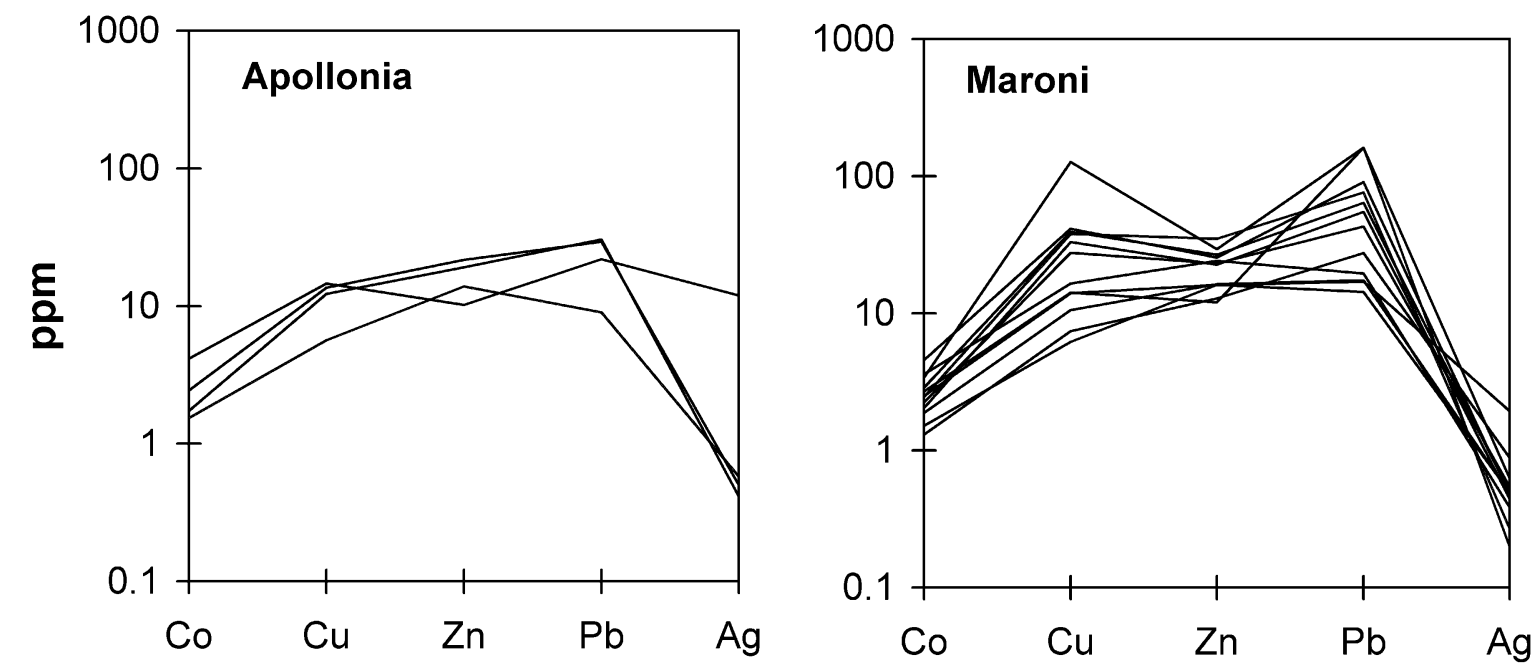

Fig. 10. Colourant elements in vessels from Maroni Petrera, compared with concentrations in raw glass from Apollonia, on the Levantine coast. 
some of which was coloured and incorporated into the remelted batch. At these levels, the transition metals have little effect on the colour of the glass, but are clearly present at concentrations above those encountered in freshly made glass sampled from tank furnaces, or those expected in mature sands. Elements such as $\mathrm{Cu}, \mathrm{Co}, \mathrm{Pb}, \mathrm{Mn}$, $\mathrm{Sb}$, which are associated with colouration, decolouration and opacification processes, along associated elements such as $\mathrm{Ag}$ and $\mathrm{Zn}$, can be misleading as their concentrations are related to the particular mix of recycled glass used in a specific batch. They can therefore give rise to compositional subgroups which are not related to the origin of the primary glass.

Even where evidence of other colourants is absent, manganese oxide may be elevated, as pyrolusite $\left(\mathrm{MnO}_{2}\right)$ was used as an oxidant in Roman and Islamic glassmaking to minimise the blue colour due to divalent iron (Sayre 1963). Many Roman glasses contain low levels of $\mathrm{MnO}$ in the order of $0.1-0.2 \%$, in the presence of around $0.4 \%$ $\mathrm{FeO}^{\mathrm{t}}$. Whether additions of manganese at such low levels would have effectively decolourised the glass is doubtful. However, as $\mathrm{MnO} / \mathrm{FeO}$ averages 0.015 in the Earth's crust (Wedepohl 1995) the probability is that these levels do represent deliberate addition at some point during the manufacturing and recycling history of the glass. Technological factors, such as colouration and decolouration of the glass, and the initial sand : soda ratio chosen by the glassmaker, need to be taken into consideration when analysing glass compositional data.

There are literary references to hawkers on the streets of Rome who collected glass for recycling (Whitehouse 1999; Keller 2005), and it is becoming increasingly clear from compositional studies that the recycling of glass was widely practised. However, in general, the recycling process does not appear to have resulted in the blurring of the compositional differences between primary production groups. The same glass compositional groups may coexist and show clear compositional separation in localities as diverse as Cyprus, Egypt and Italy (Freestone et al 2002a,b, Foy et al. 2003a,b). This apparent paradox may be attributed to several factors. First, for significant periods of time, glass working in a region tended to depend on a single production centre for the supply of raw glass. Thus recycling, which is likely to have been carried out on an intra-regional basis, will have been mixing glass of the same basic type. The apparent co-existence of separate compositional groups may in some cases reflect poor chronological resolution; their use may have been separated by a decade or more. Furthermore, it is likely that glassmakers tried to avoid mixing glasses of different colour. For example, colourless glass would have been spoiled by mixing it with blue-green glass. The traces of colourant that have been interpreted as evidence of recycling in this paper may reflect carelessness on the part of the craftsman, unavoidable contamination through the inclusion of coloured handles, decorative spots etc., and confidence that the inclusion of a small amount of coloured glass would not affect the colour of the batch.

It would appear that Levantine glass producers not only supplied the eastern Mediterranean but much of the early medieval world. Levantine glass appears to be present in assemblages in Italy, dating to around the fifth century (Freestone et al. 2002b) and in France (Foy et al. 2003a). Fig. 11 compares trace element distributions in window glass from Jarrow, Northumbria, UK, dating to the $7^{\text {th }}$ century A.D., with primary glasses from the Levant. The Saxon glasses show the characteristic trace element profile of Levantine production and it seems very likely that the origin of the 


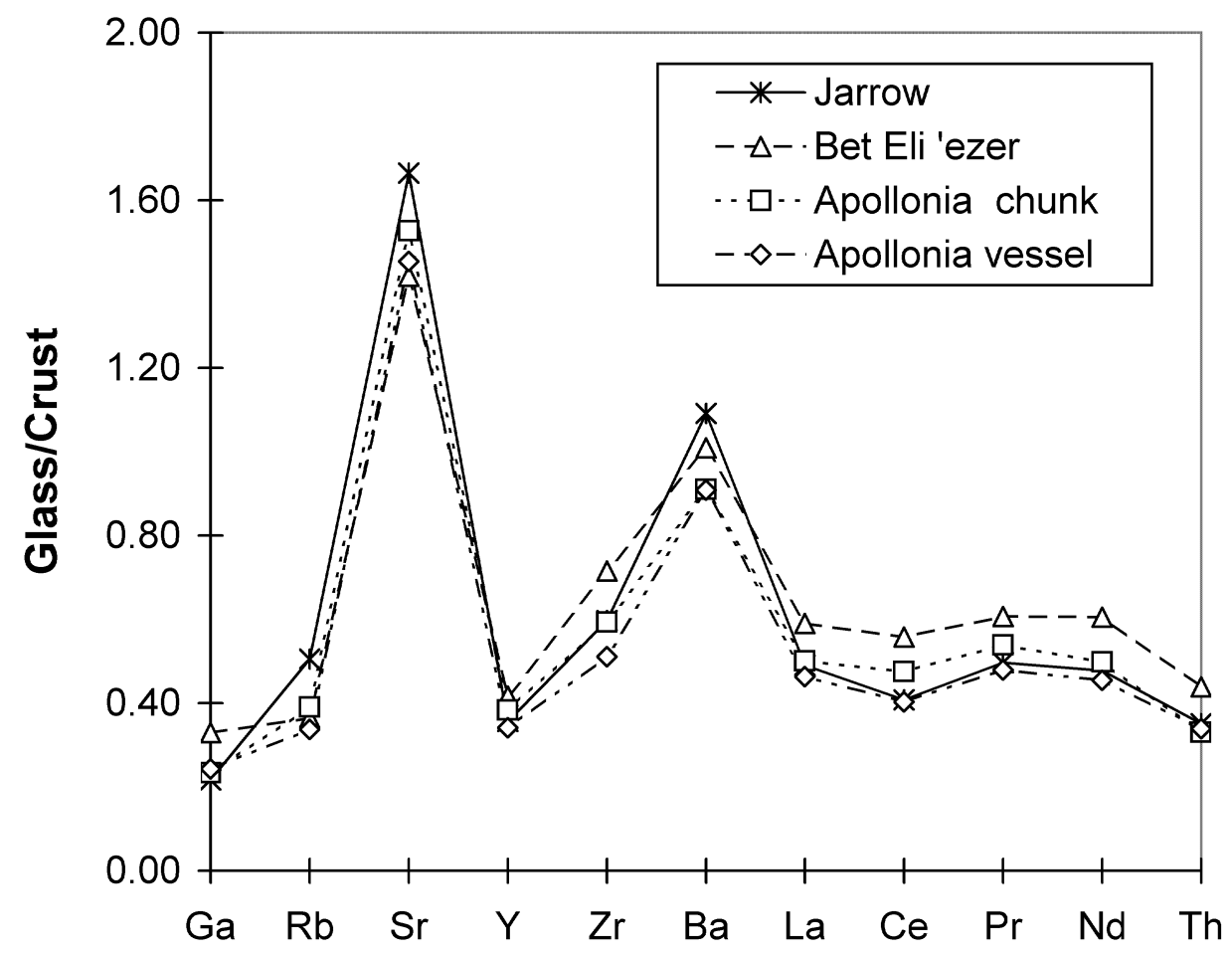

Fig. 11. Trace elements in window glass from the monastery at Jarrow, Northumbria, compared with raw glass and vessel glass from the Levant.

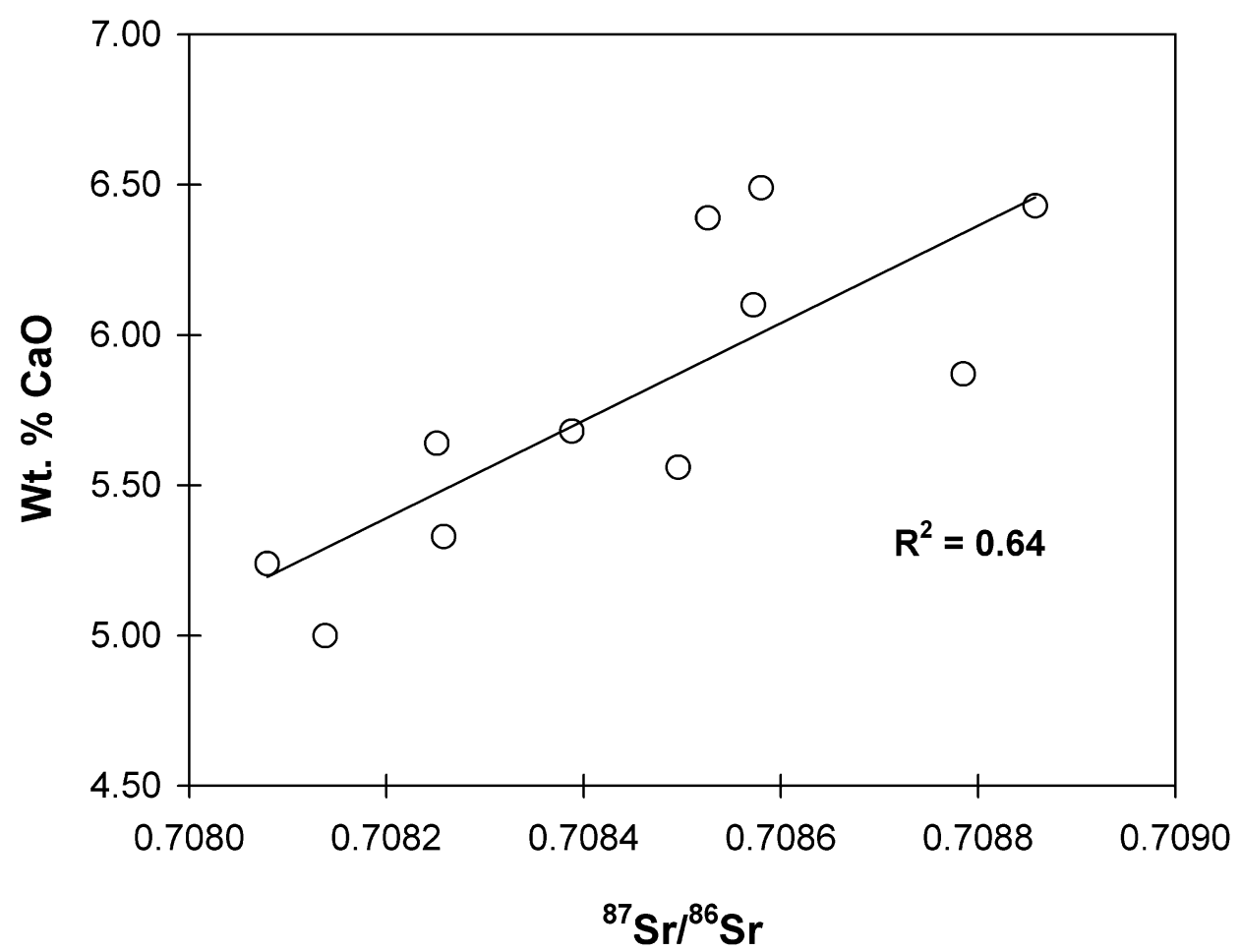

Fig. 12. Correlation between ${ }^{87} \mathrm{Sr} /{ }^{86} \mathrm{Sr}$ and $\mathrm{CaO}$ in HIMT glass. 
glass was in the Levant. It is not at this stage clear whether raw lumps of glass were arriving into Britain from the Near East; the glass may have arrived as cullet from continental Europe, to be remelted by glass workers in England (Freestone 2003).

Other primary production centres which were operative in the period under consideration include that which produced so-called HIMT glass, labelled on account

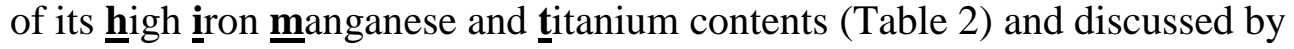
Freestone et al. (2005). Glasses of this group frequently show a strong linear relationship between the constituent oxides, and also between strontium and lead isotope and oxide compositions (Fig. 12). They appear to represent the mixing of two end-members, one based upon typical coastal sand with high ${ }^{87} \mathrm{Sr} /{ }^{86} \mathrm{Sr}$, the other with a higher terrigenous component, lower in radiogenic Sr. Freestone et al. (op. cit.) suggest that these mixed compositions may reflect a source on the coast closer to the mouth of the Nile, where sands with variable amounts of terrigenous components may be juxtaposed. HIMT glass is found extensively in the North Sinai, and occurs as far away as fourth century Roman Britain (Freestone et al. 2005).

It seems increasingly likely that much of the glass of the first millennium A.D. originated in the primary production centres of Syria-Palestine and Egypt. In this region were found the major deposits of soda and also glassmaking sands which combined the desirable properties of low iron contents and moderate lime, needed to make good quality soda-lime-silica glass. Furthermore, large deposits of the widely used decolourant, pyrolusite, occur in the Sinai. The location of the primary glass industry, as currently understood, is a clear reflection of the over-riding influence of the location of raw materials.

Fuel would have been required in large quantities to feed the furnaces which produced the primary glass. At the present time, there are no published data on the nature of the fuel used in the primary glassmaking furnaces of the Levantine coast and Egypt but, given the regional climate, the requirements of glassmaking might be expected to have placed considerable demands on the fuel supply. The existence of 17 furnaces, each producing around eight tons of glass in a single firing, at Bet Eli'ezer in Israel (Gorin-Rosen 1995, 2000) indicates that fuel supply issues were resolved, but the mechanism is not yet understood. It is possible that glass furnaces were located according to locally available fuel sources, and moved within the region when fuel was exhausted. This would be consistent with the known locations of primary workshops.

An outstanding issue is the origin of the blue-green transparent glass so common on Roman sites of the first-third centuries A.D. (Table 2). Picon and Vichy (2003, also Nenna et al. 1997) argue cogently that this glass is compositionally of the Levantine type, and indeed in terms of major elements it is very close. However, the match is not exact; the raw glass recovered so far from Levantine workshops has higher alumina than Roman glass from western Europe (Freestone et al. 2000). Variations in major element composition of this magnitude are found in primary glasses made in the Levant (e.g. Fig. 7). However, recent work using oxygen isotopes also suggests a mismatch, although this involves comparison of data from different laboratories and must be regarded as provisional (Leslie et al., in press). One problem is that glasses of different date are being compared. The primary furnaces discovered so-far appear to be late Byzantine-early Islamic, several centuries later than the Roman glass. 
These relatively minor differences might be accounted for by the variations in sand composition along the eastern Mediterranean coast (fig. 5), and it is also noted that the sedimentary load of the Nile has varied significantly over the past 7000 years due to climatic change (Krom et al. 2002), which may have resulted in some variation in the sediment supply over the several centuries under consideration here. However, given the indication by Pliny (Eicholz 1962) that glass was also made in Italy and the western provinces, some prudence is needed. It is clear that glass production in the Roman period was massive: a single building, the Baths of Caracalla in Rome, contained 16, $900 \mathrm{~m}^{2}$ of glass mosaic (Stern 1999), which would represent in the order of $200 \mathrm{t}$ of raw glass. That the installations which produced glass on such a scale have not yet been discovered is surprising, and is an indication of the limitations of our current understanding of Roman glass production.

\section{Towards the provenance of plant ash glasses}

Recent work suggests that it will be possible to group the compositions of plant ash (high-magnesia) glasses according to source, even if it will not be possible to identify the locations of the sources in all cases. In particular, production assemblages of plant ash glass from the eastern Mediterranean region dating from the ninth-eleventh centuries have been analysed, for example, glass melted at el-Raqqa in Syria (Henderson et al. 2004), glass from the large primary furnaces at Tyre (Freestone 2002), lumps of raw glass and cullet at Banias (Freestone et al. 2000) and raw lumps and cullet from the Serçe Limani wreck (Brill 1999). These demonstrate that plant ash glasses fall into coherent compositional production groups in terms of their major element compositions (Freestone 2002; Henderson 2003). Furthermore, as shown in Fig. 2, it is possible that the blanket term "plant ash glass" conflates different technological traditions which, when fully understood, will help to refine approaches to this type of glass (see also Henderson et al. 2004).

Plant ash glass is more complex than glass produced from mineral soda. Whereas mineral soda typically contributes less than $25 \%$ of a glass composition and is essentially a diluent of the silica-bearing component, plant ash is a complex material, carrying many minor and trace elements at similar levels of abundance to the source of silica. Elementary considerations suggest that it makes up at least $30 \%$ of a glass batch and, given that plant ashes frequently contain combined silica, alumina and iron in excess of $10 \%$ (Brill 1970, 1999), it is probable that in some cases $40 \%$ of the material of a plant ash glass was derived from the plant ash itself. It is not inconceivable therefore that the same silica source may have been fused with different plant ashes at different times, while it is certain that the same types of plant ash were fused with different silica sources as there was an extensive trade in plant ash in the medieval period, when ashes from Syria were imported into Europe to make glass (Ashtor and Cevidalli 1983; Jacobi 1993). In addition, as indicated above, it is still not entirely clear how the composition of the final glass plant ash corresponds to that of the raw material batch.

In spite of the complex nature of plant ash glass production, provisional investigations into the trace element and isotopic compositions of plant ash glasses indicate that they can be very variable and suggest that there is considerable potential for the discrimination of different production centres. For example, trace element 
distributions in three Islamic-period glasses from Ras al Hadd, Oman, are shown in Fig. 13, from a pilot study carried out by the author. They show clear differences in composition, which are large compared to those observed in low-magnesia glasses, and are likely to correspond to different origins of the glass types.

The isotopes of strontium and oxygen also show some potential to distinguish plant ash glass groups. Strontium can be expected to have been derived from the plant ash used to make the glass, and in turn this will reflect the bioavailable strontium of the soil on which the plants grew. Oxygen, on the other hand, will be more closely related to the silica source, as the majority of oxygen enters the glass with the silica. ${ }^{87} \mathrm{Sr} /{ }^{86} \mathrm{Sr}$ and $\delta^{18} \mathrm{O}$ are thus complimentary sources of information, and offer considerable potential for the investigation of plant ash glass when employed together. Fig. 14 presents ${ }^{87} \mathrm{Sr} /{ }^{86} \mathrm{Sr}$ versus $\delta^{18} \mathrm{O}$ for three groups of plant ash glass from Syria-Palestine, dated to between the ninth and the thirteenth centuries. The material from Tyre, Lebanon is from a primary production site (Freestone 2002), that from Banias, Israel is raw glass from a secondary production site (Freestone et al 2000) and that from el-Raqqa, Syria from a workshop that was apparently involved in primary and secondary production (Henderson et al. 2004). Isotopic data are from several sources (Freestone et al. 2003; Henderson et al. 2005; Leslie et al., in press). It can be seen that Tyre and Raqqa glasses are well separated by ${ }^{87} \mathrm{Sr} /{ }^{86} \mathrm{Sr}$, suggesting that the plant ashes were derived from different regions. Coupled with a suggestion of a difference in oxygen isotope ratios, which needs confirmation with more data, it appears that these glasses were produced in different areas from two different sets of raw materials. While the Raqqa glasses are separated from those of Tyre in terms of $\delta^{18} \mathrm{O}$, they overlap in terms of ${ }^{87} \mathrm{Sr} /{ }^{86} \mathrm{Sr}$ (Fig. 14). This is quite likely to be coincidental, but it could suggest the exploitation of plant ash from the same region of Syria. This would not be surprising, given the widespread trade in plant ash. The difference in $\delta^{18} \mathrm{O}$ is to be expected, as Henderson et al. (2005) interpret the Raqqa glasses to have been made using quartz pebbles, whereas sand was the starting material for the Tyre glasses (Fig. 4). The interpretation that these two groups of glasses may have been made using the same alkali, but different silica sources, whether or not it is proved ultimately to be correct, would not have been possible without the isotopic data, and indicates the potential of the technique.

\section{Conclusions}

Glass provides an excellent example of the importance of the production model in the interpretation of archaeometric data. The recognition that production was divided into primary and secondary workshops is at last allowing compositional data on glass from the period of interest to be interpreted in terms of origin. Furthermore, it defines new questions and allows the construction of appropriate sampling strategies for problem resolution.

Within the framework of a realistic production model, an understanding of the geochemistry of the raw materials is invaluable; it explains the choices made by the glassmakers and offers approaches to address problems of technology and origin. Furthermore, by providing an explanation of compositional variation, it strengthens confidence in interpretation and allows extrapolation. In addition, the chemistry of 


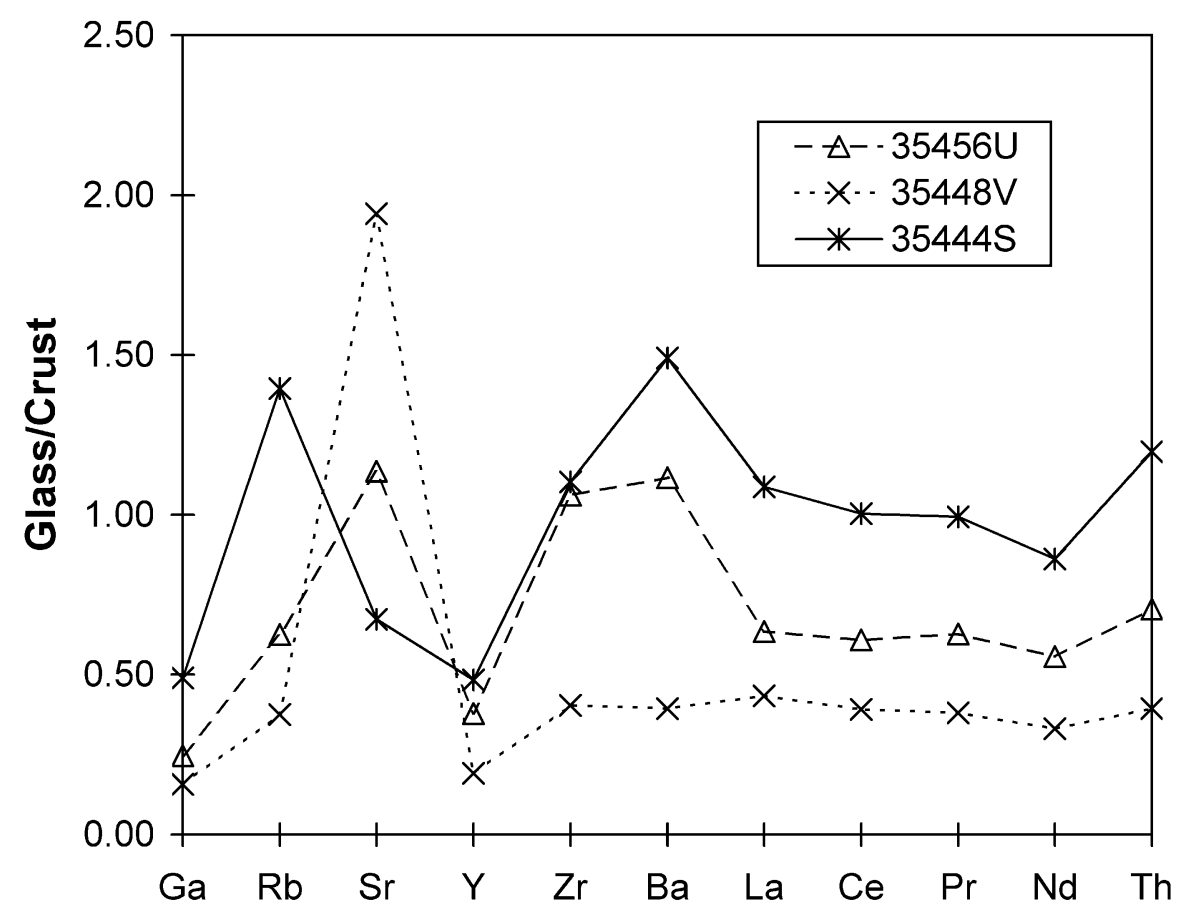

Fig. 13. Trace element distributions in three glass vessels from Ras al Hadd, Oman.

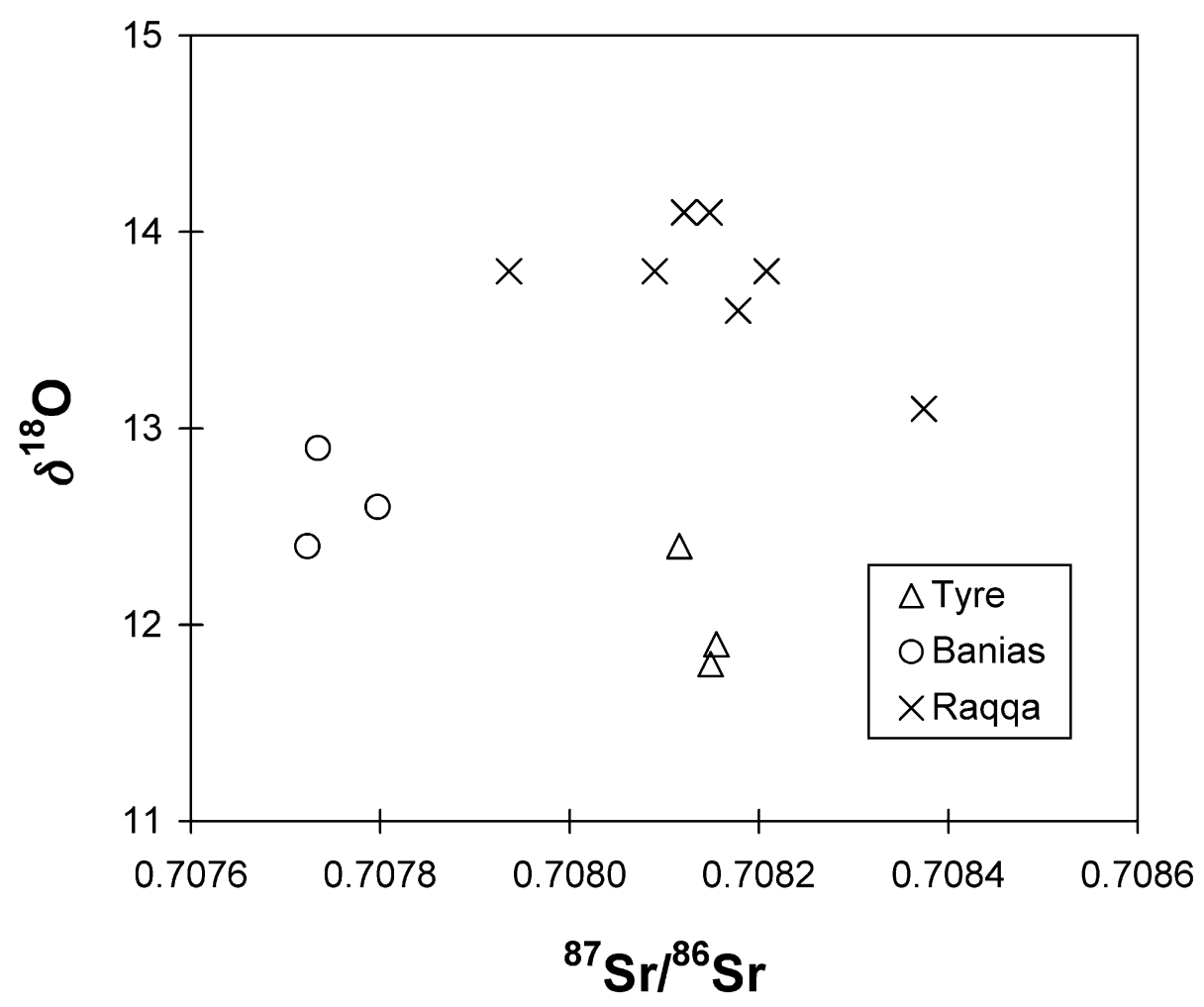

Fig. 14. Strontium and oxygen isotope data for three groups of plant ash glass. 
glass is in some respects more complex than that of clay-based ceramic as many different components can be added by the glassmaker in the form of colourants and opacifiers. Glass may also be recycled. These practices can have a significant influence on composition and must be allowed for if compositional groupings are to be meaningfully interpreted.

By taking into account the environmental and cultural factors that determine the composition of glass, it is possible to develop and extend approaches to the determination of glass provenance. Significant progress in this area has been achieved and more may be expected over the next few years.

I thank an anonymous referee for his helpful comments on this paper. I am grateful to the many archaeologists who have advised on and provided access to material for analysis, especially Y. Gorin-Rosen for her hospitality and generosity. M. J. Hughes, K. A. Leslie, K. Matthews and C.P. Stapleton are thanked for their collaboration in the laboratory. The late T.L. Martin generously funded many analyses through the Renaissance Trust and S. G. E. Bowman, Keeper of Scientific Research at the British Museum, gave her unstinting support.

\section{References}

Aldsworth, F., Haggarty G., Jennings S. \& Whitehouse D. 2002. Medieval Glassmaking at Tyre, Lebanon. Journal of Glass Studies, 44, 49-66.

Ashtor, E. \& Cevidalli, G. 1983. Levantine alkali ashes and European industries. European Journal of Economic History 12, 475-522.

Barber, D.J. \& Freestone I. C. 1990. An investigation of the origins of the colour of the Lycurgus Cup by analytical transmission electron microscopy. Archaeometry 32 33-45.

Bateson, H.M. and Turner, W.E.S. 1939. A note on the solubility of sodium chloride in a soda-lime-silica glass. Journal of the Society of Glass Technology 23, 265-67T.

Brill R. H. 1967. A great glass slab from ancient Galilee. Archaeology 20, 89-95.

Brill R. H. 1970. The chemical interpretation of the texts. In: Oppenheim, A.L., Brill, R.H., Barag, D. \& von Saldern, A. Glass and Glassmaking in Ancient Mesopotamia. (New York, Corning Museum of Glass) 105-128.

Brill R.H. 1987. Chemical analysis of some early Indian glasses. In: Bhardwaj, H. C. (ed.) Archaeometry of Glass (Proc XIV International Congress on Glass, New Delhi 1986) Indian Ceramic Society, Calcutta, 1-25.

Brill, R.H. 1988. Scientific investigations. In: Weinberg G. D., Excavations at Jalame: Site of a Glass Factory in Late Roman Palestine University of Missouri, Columbia, 257-294. 
Brill, R. H. 1995. Chemical analysis of some glass fragments from Nishapur in the corning museum of glass. In: Kröger, J. Nishapur- glass of the Islamic period.: Metropolitan Museum of Art, New York, 211-233.

Brill, R.H. 1999. Chemical Analyses of Early Glasses. Corning Museum of Glass, New York.

Brill, R H. \& Martin, J. H. (eds.) 1991 Scientific Research in Early Chinese Glass, Corning Museum of Glass, New York

Brill, R.H., Clayton, R.N., Mayeda, T.K. \& Stapleton, C.P. 1999 Oxygen Isotope Analyses of Early Glasses. In: Brill, R.H. Chemical Analyses of Early Glass, Corning Museum of Glass, New York, pp. 303-322.

Eicholz, D.E. 1962 Pliny - Natural History Books 36-37. Loeb Classical Library, Harvard.

Emery, K.O. \& Neev, D. 1960. Mediterranean Beaches of Israel. Geological Survey Israel Bulletin, 26, 1-23.

Foy, D., Vichy, M. \& Picon, M. 2000. Lingots de verre en Méditerrané occidentale. Annales 14th congrès de l'Association pour l'Histoire du Verre, AIHV, Amsterdam, 51-57.

Foy, D., Picon, M., Vichy, M., \& Thirion-Merle, V. 2003a. Caractérisation des verres de la fin de l'Antiquitéen Méditerranée occidentale: l'emergence de nouveaux courants commerciaux. In: Foy, D. and Nenna, M-D. (eds.) Échanges et Commerce du Verre dans le Monde Antique Éditions Monique Mergoil, Montagnac, 41-85.

Foy D., Picon, M., \& Vichy, M. 2003b. Verres Omeyyades et Abbasides d'origine Egyptienne: Les temoignages de l'archéologie et de l'archéometrie. Annales $15^{e}$ Congrès de l'Association Internationale pour l'Histoire du Verre, 138-143.

Freestone, I.C. 1991. Technical examination of Neo-Assyrian glazed wall plaques, Iraq, 53 55-8.

Freestone, I.C. 2002. Composition and Affinities of Glass from the Furnaces on the Island Site, Tyre. Journal of Glass Studies, 44, 67-77.

Freestone, I. C. 2003. Primary glass sources in the mid-first millennium A.D. Annales du 15e congrès de l'Association Internationale pour l'Histoire du Verre, 111-115.

Freestone, I.C. \& Gorin-Rosen, Y. 1999. The great glass slab at Beth She'arim: an early Islamic glass-making experiment? Journal of Glass Studies, 41, 105-116.

Freestone, I.C., Gorin-Rosen, Y. \& Hughes, M.J. 2000. Composition of primary glass from Israel. In: Nenna, M.-D. (ed.) Ateliers primaires et secondaires de verriers du second millinaire av. J.-C. au Moyen-Age, Travaux de la Maison de l'Orient Méditerranéen no. 33, Lyon, 65-84. 
Freestone, I. C., Ponting, M. \& Hughes, M. J. 2002a. Origins of Byzantine glass from Maroni Petrera, Cyprus. Archaeometry 44, 257-272.

Freestone I. C.,, Greenwood R. \& Gorin-Rosen Y. 2002b. Byzantine and early Islamic glassmaking in the Eastern Mediterranean: production and distribution of primary glass. In: Kordas, G. ( ed) Hyalos - Vitrum - Glass. History Technology and Conservation of glass and vitreous materials in the Hellenic World. 1st International conference Rhodes - Greece 1-4 April 2001. Athens , 167-174.

Freestone I. C., Leslie K. A., Thirlwall M. \& Gorin-Rosen Y., 2003. Strontium isotopes in the investigation of early glass production: Byzantine and early Islamic glass from the Near East. Archaeometry 45, 19-32

Freestone, I.C., Wolf, S. \& Thirlwall, M. 2005. The production of HIMT glass: elemental and isotopic evidence. Annales du 16e Congrès de l'Association Internationale pour l'Histoire du Verre. 153-157.

Glover I. \& Henderson J. 1995. Early glass in South and South East Asia and China. In: Scott, R. \& Guy J. (eds.) South East Asia and China: Art, Interaction and Commerce. Percival David Foundation of Chinese Art, Colloquies on Art and Archaeology in Asia no. 17, London, 141-169.

Goldsmith, V. \& Golik, A. 1980. Sediment transport model of the southeastern Mediterranean coast. Marine Geology 37, $147-175$.

Gorin-Rosen, Y. 1995. Hadera, Bet Eli'ezer. Excavations and Surveys in Israel, 13, 42-43.

Gorin-Rosen, Y. 2000. The ancient glass industry in Israel: summary of new finds and new discoveries. In: Nenna, M.-D. (ed.), Ateliers primaires et secondaires de verriers du second millinaire av. J.-C. au Moyen-Age, Travaux de la Maison de l'Orient Méditerranéen no. 33, Lyon, 49-63.

Gratuze, B. \& Barrandon, J-N. 1990 . Islamic glass weights and stamps: analysis using nuclear techniques. Archaeometry, 32, 155-162.

Henderson J. 2003. Glass trade and chemical analysis: a possible model for Islamic glass production. In : Foy, D. and Nenna, M.-D. (eds.). Échanges et Commerec du Verre dans le Monde Antique. Montagnac: Éditions Monique Mergoil, 109-124.

Henderson, J., McLoughlin, S.D. and McPhail, D.S. 2004. Radical changes in Islamic glass technology: evidence for conservatism and experimentation with new glass recipes from early and middle Islamic Raqqa, Syria. Archaeometry, 46, 439-468.

Henderson, J., Evans J. A., Sloane H.J., Leng M. J. \& Doherty C. 2005. The use of strontium, oxygen and lead isotopes to provenance ancient glasses in the Middle East. Journal of Archaeological Science. 32, 665-674. 
Hunter, J. \& Heyworth, M. 1998. The Hamwic Glass. Council for British Archaeology, York (Research Reports 116)

Jackson, C. M., Hunter, J. R., Warren, S. E. \& Cool, H.E.M., 1991. The analysis of blue-green glass and glassy waste from two Romano-British glass-working sites. In: Pernicka E. and Wagner G. A. (eds). Archaeometry '90, Birkhauser Verlag, Basel, 295-305.

Keller, D. 2005. Social and economic aspects of glass recycling In: Bruhn, J., Croxford, B. \& Grigoropoulos, D. (eds.) TRAC 2004: Proc. 14 ${ }^{\text {th }}$ Annual Theoretical Roman Archaeology Conference. Oxbow. 65-78.

Krom, M. D., Stanley, J. D., Cliff, R. A. \& Woodward, J. C. 2002. Nile river sediment fluctuations over the past $7000 \mathrm{yr}$ and their key role in sapropel development. Geology 30, 71-74.

Leslie, K. A., Freestone, I. C., Lowry, D. \& Thirlwall, M. (in press) provenance and technology of near eastern glass: oxygen isotopes by laser fluorination as a compliment to strontium. Archaeometry

Lilyquist, C. and Brill, R. H. 1993 Studies in Early Egyptian Glass. The Metropolitan Museum of Art, New York.

Moorey, P. R. S. 1994. Ancient Mesopotamian Materials and Industries Oxford

Nenna, M-D., Vichy, M. \& Picon, M. 1997. L'Atelier de verrier de Lyon, du Ier siècle après J.-C., et l'origine des verres "Romains". Revue d'Archèomètrie, 21, 8187.

Nenna M-D., Picon M. and Vichy M., 2000. Ateliers primaires et secondaires en Égypte à l'époque gréco-romaine. In : Nenna M.-D. (ed.) La Route du Verre: Ateliers primaires et secondaires de verriers du second millénaire av. J.-C. au Moyen-Âge, Travaux de la Maison de l'Orient Méditerranéen no. 33, Lyon, 97-112.

Nenna, M-D., Picon, M., Thirion-Merle, V. \& Vichy, M. 2005. Ateliers primaires du Wadi Natrun : nouvelles découvertes. Annales du 16e Congrès de l'Association Internationale pour l'Histoire du Verre 59-63.

Nicholson, P. T., Jackson, C. M. \& Trott, K. M. 1997. The Ulu Burun glass ingots, cylindrical vessels and Egyptian glass. Journal of Egyptian Archaeology 83, 143-153.

Oppenheim, A.L., Brill, R.H., Barag, D. \& von Saldern, A. 1970. Glass and Glassmaking in Ancient Mesopotamia. Corning Museum of Glass, New York.

Picon, M. and Vichy, M. 2003. D'Orient en occident: l'origine du verre à l'époque romaine et durant le haut Moyen Âge. In : Foy, D. and Nenna, M.-D. (eds.). Échanges et Commerce du Verre dans le Monde Antique. Éditions Monique Mergoil, Montagnac, 17-31. 
Pomerancblum, M. 1966. The distribution of heavy minerals and their hydraulic equivalents in sediments of the Mediterranean continental shelf of Israel. Journal of Sedimentary Petrology 36, 162-174.

Reade, W., Freestone, I.C. and Simpson, St J. 2005. Innovation or continuity ? Early first millennium BCE glass in the Near East : The cobalt blue glass from Assyrian Nimrud. Annales du l6e Congrès de l'Association pour l'Histoire du Verre 23-27.

Rehren, Th. 2000. Rationales in Old World base glass compositions. Journal of Archaeological Science 27, 1225-1234.

Rehren, Th. \& Pusch, E. B. 1997. New Kingdom glass-melting crucibles from Qantir-Piramesses. Joural of Egyptian Archaeology 83, 127-141.

Sayre, E. V. \& Smith, R. W. 1961. Compositional categories of ancient glass. Science 133, 1824-1826.

Sayre, E. V. 1963. The intentional use of antimony and manganese in ancient glasses. In: Matson, F. R. \& Rindone, G. E. (eds.), Advances in Glass Technology, Part 2: Plenum Press, New York, 263-282.

Shortland, A.J. 2004. Evaporites of the Wadi Natrun: seasonal and annual variation and its implication for ancient exploitation. Archaeometry, 46, 497-516.

Shortland, A.J., Schachner, L., Freestone, I.C. \& Tite, M. (in press) Natron as a flux in the early vitreous materials industry - sources, beginnings and reasons for decline. Journal of Archaeological Science.

Shugar, A. and Rehren, Th. 2002. Formation and composition of glass as a function of firing temperature. Glass Technology 43C (Proceedings XIX Internatioanl Congress on Glass, Edinburgh, 1-6 July 2001) 145-50.

Smith, R.W. 1963. Archaeological evaluation of analyses of ancient glass. In: Matson, F. R. \& Rindone, G. E. (eds.), Advances in Glass Technology, Part 2: Plenum Press, New York,.283-290.

Stanley, D.J., Mart, Y. \& Nir, Y. 1997. Clay mineral distributions to interpret Nile cell provenance and dispersal: II. Coastal plain from Nile delta to northern Israel. Journal of Coastal Research, 13, 506-533.

Stapleton, C.P. \& Swanson, S.E. 2002. Chemical analysis of glass artefacts from Iron Age levels at Hasanlu, northwestern Iran. Glass Technology 43C (Proceedings of the XIX International Congress on Glass), 151-157.

Stern, E. M. 1999. Roman glassblowing in a cultural context. American Journal of Archaeology 103, 441-484.

Tal, O., Jackson-Tal, R.E. and Freestone, I.C. 2004. New Evidence of the Production of Raw Glass at Late Byzantine Apollonia-Arsuf (Israel). Journal of Glass Studies, 46, 51-66. 
Verità, M. 1985. L'Invenzione del cristallo Muranese: una verfica analitica delle fonti storiche. Rivista delle Stazione Sperimentale del Vetro 1, 17-36.

Wedepohl, K. H., 1995. The Composition of the Continental Crust. Geochimica et Cosmochimica Acta 59, 1217-1232.

Wedepohl K. H. 2003. Glas in Antike und Mittelalter. E. Schweizbart'sche Verlagsbuchhandlung, Stuttgart.

Wedepohl, K. H. \& Baumann, A. 2000. The use of marine molluskan shells for Roman glass and local raw glass production in the Eifel area (Western Germany). Naturwissenschaften 87, 129-132.

Whitehouse, D. 1999. Glass in the Epigrams of Martial. Journal of Glass Studies 41, 73-81.

Whitehouse, D. 2002. The transition from natron to plant ash in the Levant Journal of Glass Studies 44, 193-196. 